\title{
BETWEEN DEATH AND DIVINITY. \\ RETHINKING THE SIGNIFICANCE OF TRIADIC GROUPS \\ IN ANCIENT MAYA CULTURE
}

\author{
JAN SZYMAŃSKI \\ Centre for Precolumbian Studies, \\ University of Warsaw
}

Resumen: En este artículo se intenta reunir una lista lo más completa posible de los grupos triádicos registrados en el área maya para, posteriormente, analizar diversos aspectos de su presencia y cronología, su arquitectura, contextos urbanos e iconografía, a fin de poder re-evaluar las dos teorías existentes y proponer una nueva. La conclusión final establece que ambas propuestas, a saber, la concepción de los grupos triádicos como réplicas terrenales del "hogar cósmico" o como escenarios arquitectónicos de ritos de adhesión al trono, no pueden descartarse por completo. Sin embargo, estas teorías demuestran posibles funciones y significados secundarios de los grupos triádicos, limitados a cierto número de los conjuntos conocidos actualmente. Se presenta una interpretación más general según la cual los grupos triádicos pueden ser percibidos como escenarios arquitectónicos y réplicas de la mítica "montaña florida" en el preciso momento de la resurrección del dios del maíz.

Palabras clave: grupo triádico, dios del maíz, Montaña de las Flores, arquitectura maya, conjuntos especializados.

ABSTRACT: This paper aims to gather the most complete list of recorded Triadic Groups from the Maya Area, and subsequently analyze various aspects of their spatial and temporal occurrence, as well as their architecture, urban context, and iconography, in order to re-evaluate the existing theories and, possibly, arrive at a new one. The final conclusion states that both previously existing theories, namely those interpreting Triadic Groups as either earthly replicas of the Cosmic Hearth, or architectural stages for king's accession rituals, cannot be entirely dismissed. However, they demonstrate possible secondary functions and meanings of the Triadics, limited to a certain number of known triadic assemblages. A more general interpretation is introduced, according to which Triadic Groups can be perceived as architectural stages and replicas of the Flower Mountain at the specific moment of the Maize God's resurrection.

KeYworDs: triadic group, Maize God, Flower Mountain, maya architecture, specialized assemblages.

RECEPCIÓN: 9 de enero de 2014.

ACEPTACIÓn: 3 de abril de 2014. 



\title{
BETWEEN DEATH AND DIVINITY. RETHINKING THE SIGNIFICANCE OF TRIADIC GROUPS IN ANCIENT MAYA CULTURE
}

\author{
JAN SZYMAŃSKI \\ Centre for Precolumbian Studies, \\ University of Warsaw
}

\section{Introduction}

Early in their studies on ancient Maya architecture, the $20^{\text {th }}$ century scholars noticed that some buildings tend to occur in certain spatial relations to each other. A number of formal architectural groups have been identified, among them the so-called E-Groups, Twin Pyramid Groups, and Triadic Groups. Such complex architectural features, although much harder to interpret than simple, generic buildings, are considered more promising in terms of revealing ancient Maya ways of thinking and perceiving the world (Cohodas, 1985; Hansen, 1998; Aveni et al., 2003). Out of those examples, only Triadic Groups seem to lack a definite, convincing interpretation of their function and meaning. This paper aims to analyze spatial, architectural, iconographic, and urbanistic aspects of Triadic Groups throughout time and demonstrate their broader cultural context.

Triadic Groups occur widely throughout the whole Maya region - from northeastern Yucatán to Guatemalan highlands - and from the Middle or Late Preclassic until the Early Postclassic times (roughly 350 BC-AD 1250). This kind of architecture has been reported since the beginnings of the 20th century (see Tozzer, 1913: 171-175, among others), but the term "Triadic" was coined at the end of the 1980s (Matheny, 1987: 87; Valdés, 1989; Hansen, 1990: 171-172). In the 1990s and 2000s, a few attempts were undertaken to gather and analyze data in search for formal and functional patterns of Triadics, most notably papers by Hansen (1998) and Taube (1998). Some remarks on the subject can be found in Freidel et al. (1993) book. A recent book by Estrada-Belli (2011) extends the list of Triadics included in the Hansen's work, adding data obtained from the Holmul region projects in Guatemala, along with a discussion on their chronological occurrence and ritual importance at the dawn of the Maya civilization. The corpus of Triadic Groups compiled in this paper consists of 88 complexes, but their number may be far greater. For example, the Catalogue lists 10 Triadics from El Mirador, while Hansen mentions as many as 34 , though without further 
specification of the topic (Morales et al., 2008: 201). That being said, many of Triadic Groups listed in this work still await a proper archaeological investigation, and the scarcity of appropriate data excludes them from the discussion.

Unlike E-Groups, Triadics do not present standardized formal patterns. It is not to say that any group of three buildings forming a triangle shall be considered as such. A working definition of Triadic Group used in this paper has been adapted from Estrada-Belli (2011: 67-69) and modified by the author. It is based on two criteria that must be fulfilled together:

-Triadic Groups, or Triadics, are situated on elevated platforms or pyramids.

-A Triadic Group is formed by a main temple set at the back of the platform or pyramid and facing the entrance (stairway) of the platform, flanked by two other temples, usually smaller than the main one, that face each other, set at opposing lateral edges of the platform (figure 1a).
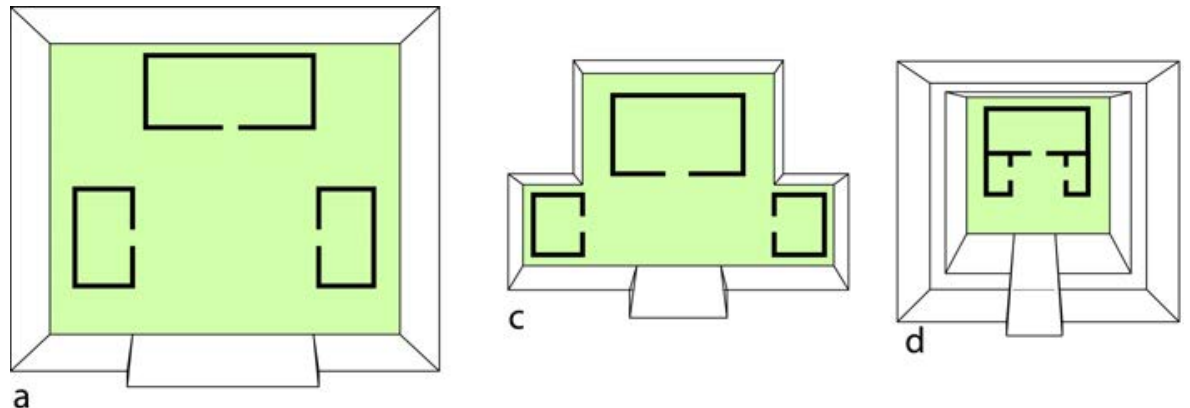

a
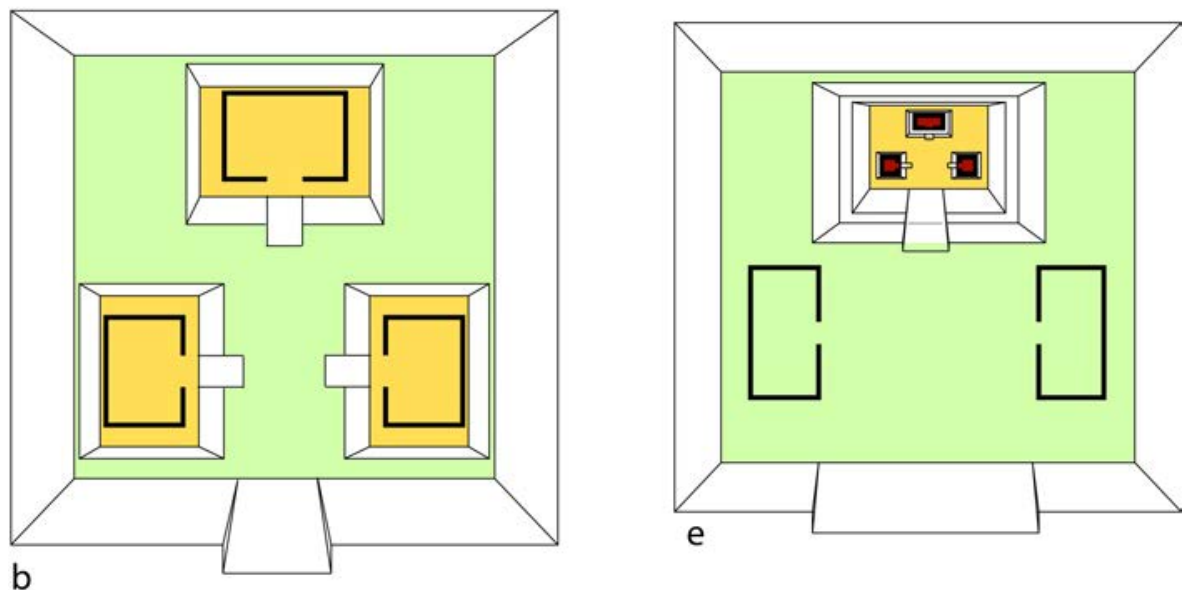

Figure 1. Typology of Triadics: a) 1-tiered, b) 2-tiered,

c) T-type, $d$ ) U-type, e) fractal-type. 
A number of secondary features, however not always present, can be observed in many cases:

- the main (central) temple of a Triadic, or all three, may be further elevated above the platform by means of pyramidal substructures ("2-tiered", figure $1 \mathrm{~b}$ );

- the entrance to the platform usually takes the form of a broad monumental stairway, frequently flanked by stucco masks;

- the triad of temples shall be considered as Triadic even when accompanied by several other buildings on the top of a platform or pyramid, as long as the latter ones do not interfere with the essential elements;

- the two lateral superstructures may be adjoining the central one ("U-type", figure 1d);

- the platform may take form of an inverted letter $T$, leaving just enough space for the three main superstructures to be constructed on top without additional space on the sides and behind the main structure ("T-type", figure 1c); - each of the superstructures constituting the triad may further feature a triadic pattern on top of its own substructures ("Fracta-type", figure 1e);

- one site may feature more than one Triadic Group.

\begin{tabular}{|c|c|c|c|}
\hline Site & Structure & Orientation & Date \\
\hline Altar de los Reyes & SE Group, Str. 1 & S & LPC \\
\hline Becán & $?$ & $?$ & LPC \\
\hline Bejucal & $?$ & W & $?$ \\
\hline Calakmul & Str. II & S & LPC - LC \\
\hline Calakmul & Str. VII & N & LPC - LC \\
\hline Caracol & Caana & N & LPC (?) - TC \\
\hline Cerros & Str. 3 & N & PC \\
\hline Cerros & Str. 4 & W & LPC \\
\hline Cerros & Str. 6 & N & LPC \\
\hline Cerros & Str. 29 & E & LPC \\
\hline Ch'el & $?$ & N & LC - TC \\
\hline
\end{tabular}

List of Triadic Groups from the Maya Area. ${ }^{1}$

${ }^{1}$ MPC-Middle Preclassic (1000-400 BC), LPC-Late Preclassic (400 BC-AD 100), PC-Protoclassic (AD 100-250), EC-Early Classic (AD 250-600), LC-Late Classic (AD 600-800), TC-Terminal Classic (AD 800900), EPsC-Early Postclassic (AD 900-1250). 


\begin{tabular}{|c|c|c|c|}
\hline Chochkitam & XV & W & $?$ \\
\hline Cival & Triadic Group & $\mathrm{E}$ & LPC \\
\hline Dzibanché & Kinichna Level C & $\mathrm{N}$ & EC - LC \\
\hline Dzibilchaltún & Str. 605 & $\mathrm{~S}$ & LPC \\
\hline Edzná & Grand Acropolis & $\mathrm{E}$ & LC - TC \\
\hline Edzná & Small Acropolis & $\mathrm{E}$ & LC - TC \\
\hline Ek Balam & X-Huyub & $?$ & LPC \\
\hline El Mirador & Structure 34 & $\mathrm{~S}$ & LPC \\
\hline El Mirador & Chicharras & $E$ & LPC \\
\hline El Mirador & Cutz & $E$ & LPC \\
\hline El Mirador & Danta & $\mathrm{E}$ & LPC - PC \\
\hline El Mirador & Kolomte & E & LPC \\
\hline El Mirador & Monos & $S$ & LPC \\
\hline El Mirador & Pava & $S$ & LPC - PC \\
\hline El Mirador & Tigre & W & LPC - PC \\
\hline El Mirador & Tres Hermanos & S & LPC \\
\hline El Mirador & Tres Micos & $\mathrm{E}$ & LPC - PC \\
\hline El Palmar & Triadic Group & W & LPC \\
\hline El Perú (Waka) & Str. $014(1-3)$ & $\mathrm{E}$ & PC - LC \\
\hline El Socotzal & Triadic Acropolis & $?$ & LPC (?) \\
\hline El Tigre (Itzamkanac) & Str. 1 (?) & $S$ & LPC \\
\hline Hahakab & Triadic Group & $\mathrm{N}$ & $?$ \\
\hline Holtún & Group A (1-7) & $\mathrm{N}$ & LPC - EC \\
\hline La Honradez & VII & $\mathrm{E}$ & $?$ \\
\hline Lamanai & Str. N9-56 & E & LPC - EC \\
\hline Lamanai & Str. N10-43 & $\mathrm{N}$ & LPC - EC \\
\hline Lamanai & Str. P9-12 & $E$ & LPC - EC \\
\hline Las Delicias & Str. 2 & $\mathrm{E}$ & EC \\
\hline
\end{tabular}




\begin{tabular}{|c|c|c|c|}
\hline Las Ruinas de Arenal & Group C & $\mathrm{E}$ & $?$ \\
\hline Mucaancah & North Acropolis, Str. 1 & $\mathrm{~N}$ & PC \\
\hline Nakbé & Str. 1 & W & LPC \\
\hline Nakbé & Str. 13 & $\mathrm{E}$ & LPC \\
\hline Nakbé & Str. 27 & $\mathrm{~N}$ & LPC \\
\hline Nakbé & Str. 78 & $\mathrm{~S}$ & LPC \\
\hline Nakum & Str. 99 & $\mathrm{~N}$ & TC \\
\hline Nakum & Interior Acropolis & $\mathrm{S}$ & LPC - TC (?) \\
\hline Nakum & Str. E & W & TC \\
\hline Nakum & Str. N & W & LC - TC \\
\hline Naranjo & Str. A-15 & $\mathrm{N}$ & TC \\
\hline Naranjo & Str. B-5 & $\mathrm{N}$ & EC - LC \\
\hline Naranjo & Str. C-3 & $\mathrm{E}$ & EC - LC \\
\hline Naranjo & Str. C-9 & $\mathrm{E}$ & LPC - TC \\
\hline Naranjo & Str. C-10 & $\mathrm{E}$ & EC - LC \\
\hline Naranjo & Str. D-1 & $\mathrm{N}$ & LPC - TC \\
\hline Nohmul & Str. $2-3$ & $\mathrm{~N}$ & EC \\
\hline Palenque & Cross Group & $\mathrm{N}$ & LC \\
\hline San Bartolo & Pinturas & $\mathrm{E}$ & LPC - PC \\
\hline San Bartolo & Ventanas & $\mathrm{N}$ & LPC - PC \\
\hline Sacnab & $?$ & $\mathrm{E}$ & MPC / LPC \\
\hline Sacul & Plaza C (1-3) & $\mathrm{N}$ & LC - TC \\
\hline Seibal & Group D Triad & $\mathrm{E}$ & LPC \\
\hline Tikal & Str. 5D-22 Triad & $\mathrm{N}$ & LPC - EC \\
\hline Tintal & Triadic Complex & $\mathrm{E}$ & LPC - PC \\
\hline Tintal & $?$ & $?$ & LPC - PC \\
\hline T'ot & $?$ & $?$ & LPC \\
\hline Tzicul & $?$ & $\mathrm{~S}$ & EC - LC \\
\hline
\end{tabular}




\begin{tabular}{|c|c|c|c|}
\hline Uaxactún & Str. A-V & $\mathrm{N}$ & EC \\
\hline Uaxactún & Group E Triad & S & LPC-EC \\
\hline Uaxactún & Group H North & $\mathrm{E}$ & LPC - PC \\
\hline Uaxactún & Str. H-I & $\mathrm{E}$ & LPC - PC \\
\hline Uaxactún & Group H South & E & LPC - PC \\
\hline Uaxactún & Str. H-X & E & LPC \\
\hline Utatlán (Qumarkaaj) & Str. RC 60 & E & $\mathrm{EPsC}$ \\
\hline Wakná & Str. 3 & $\mathrm{~N}$ & LPC \\
\hline Yaxhá & North Acropolis Triad & $\mathrm{N}$ & LPC - LC \\
\hline Yaxnohcah & Str. A-1 & $\mathrm{N}$ & LPC - EC \\
\hline Yaxuná & Str. 5E-19 Group & $S$ & LPC \\
\hline Yaxuná & $5 E-30$ & $S$ & LPC \\
\hline Yaxuná & East Acropolis & E & LPC \\
\hline Yaxuná & North Acropolis & $\mathrm{N}$ & LPC \\
\hline Xtobó & Group B & S & MPC (?) - LPC \\
\hline Xtobó & $?$ & S & $?$ \\
\hline Xualcanil & Tetunna Group & $\mathrm{N}(?)$ & $?$ \\
\hline Xulnal & $?$ & $\mathrm{E}$ & LPC (?) \\
\hline Xunantunich & A11 & $\mathrm{N}$ & LC - TC \\
\hline
\end{tabular}

\section{Spatial and Temporal Distribution of Triadic Groups}

Placing the total of 88 Triadic complexes discovered in 47 archaeological sites on a map results in receiving a visible cluster of occurrence in the center of the Maya land, especially in the central and eastern portions of the Guatemalan Petén, and southeastern Campeche in México. Another cluster, comparatively small but visible due to its isolation, populates the northwestern tip of the Yucatán peninsula. Besides these, only a few sites do not fit either cluster, being rather randomly scattered on the map (figure 2). 


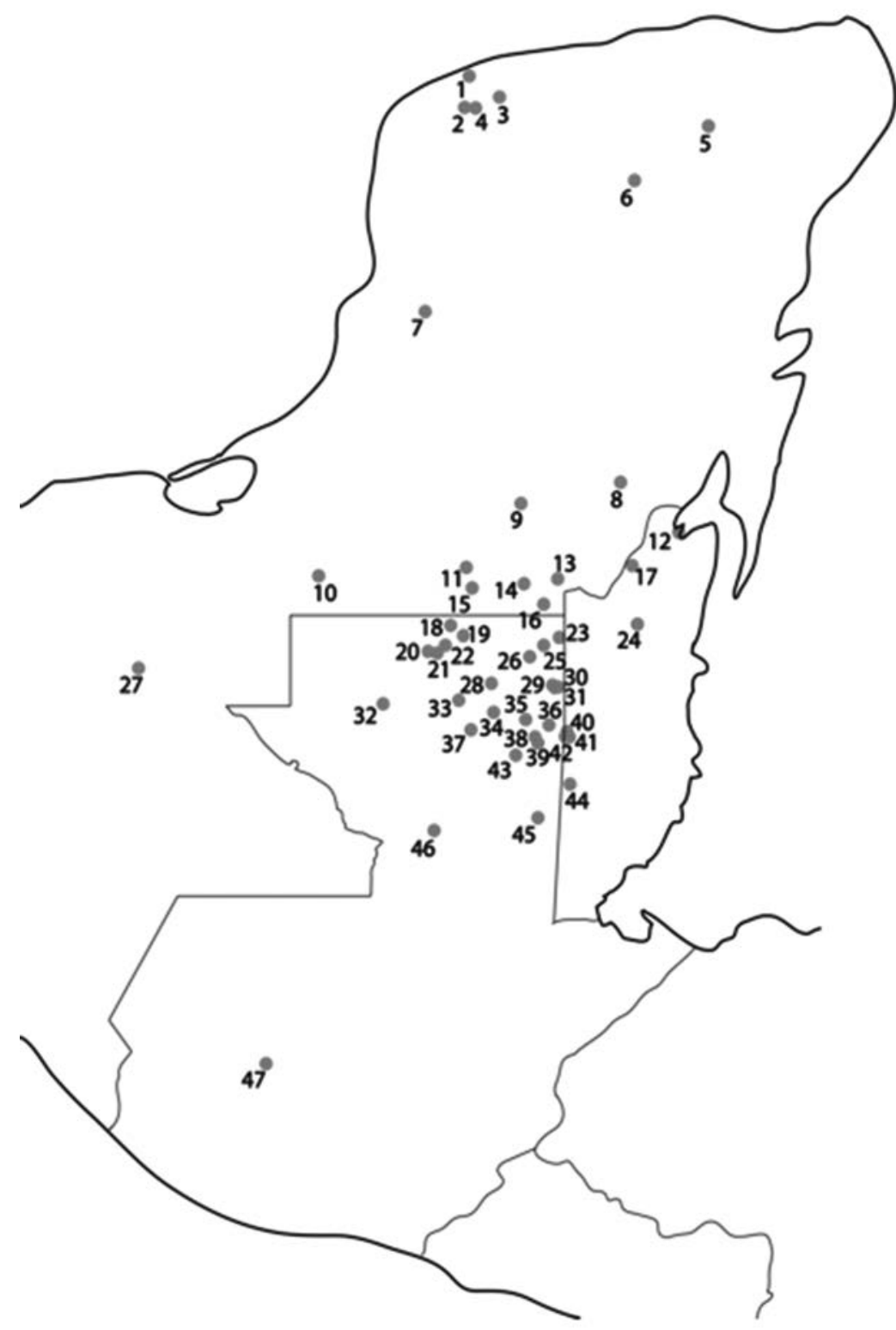

1. Tzicul

2. Ch'el

3. Dzibilchaltún

4. Xtobó

5. Ek' Balam

6. Yaxuná

7. Edzná

8. Dzibanché

9. Becán

10. El Tigre (Itzamkanac)

11. Calakmul

12. Cerros

13. Mucaancah

14. Las Delicias

15. Yaxnohcah

16. Altar de los Reyes

17. Nohmul

18. El Mirador

19. Nakbé

20. Xulnal

21. Wakná

22. Tintal

23. Chochkitam

24. Lamanai

25. La Honradez

26. San Bartolo

27. Palenque

28. Uaxactún

29. T'ot

30. Cival

31. Hanakab

32. El Perú / Waka

33. El Palmar

34. Tikal

35. Nakum

36. Naranjo

37. El Socotzal

38. Yaxhá

39. Savnab

40. Xunantunich

41. Xuacanil

42. Las Ruinas de Arenal

43. Holtún

44. Caracol

45. Sacul

46. Seibal

47. Utatlán

FigurE 2. Spatial distribution of sites featuring Triadic Groups. 
Such a distribution, however peculiar, does not permit to draw any definite conclusions; it merely points towards the origin of Triadics somewhere within the eastern Petén. In fact, some of the earliest Triadic Groups have been discovered in that area, for example in early Late Preclassic Cival (Estrada-Belli, 2006), or perhaps even earlier late Middle Preclassic Sacnab (Rice, 1976). The latter, reported during a survey and brief sampling excavation, yielded mixed Mamom and Chicanel ceramic samples, possibly being the earliest such construction known today, therefore contradicting a belief that the Triadics were a Late Preclassic architectonic innovation within the administrative or ceremonial cores, following more ancient Middle Preclassic E-Groups. Inconclusive nature of the test-pit data, though, renders such an early dating tentative.

Having a look at the orientation of particular Triadics within their respective sites, interesting information can be obtained: the northern and eastern ones are favored, meanwhile the western one occurs sporadically, in most cases as a complimentary orientation at those sites that feature more than one Triadic Group with different orientation, as seen in El Mirador, Cerros, or Nakum (Hansen, 1990; Freidel, 1986; Źrałka, 2008). However, one of the earliest Triadics, and possibly the first of such a complex at the site, is Structure 1 from Nakbé, and it is oriented due west. Also the El Palmar Triadic Group, the only Triadic at the site, features western orientation. Southern orientation prevails on the northern Yucatán, being rather randomly scaoered elsewhere (figure 3). It has to be underlined, however, that orientations of particular Triadic Groups presented in this paper are mere approximations of their actual Azimuth, rounded up to the nearest cardinal direction; it is due to the variable quality and exactitude of published plans, and lack of differentiation between the true and magnetic north in many of them.

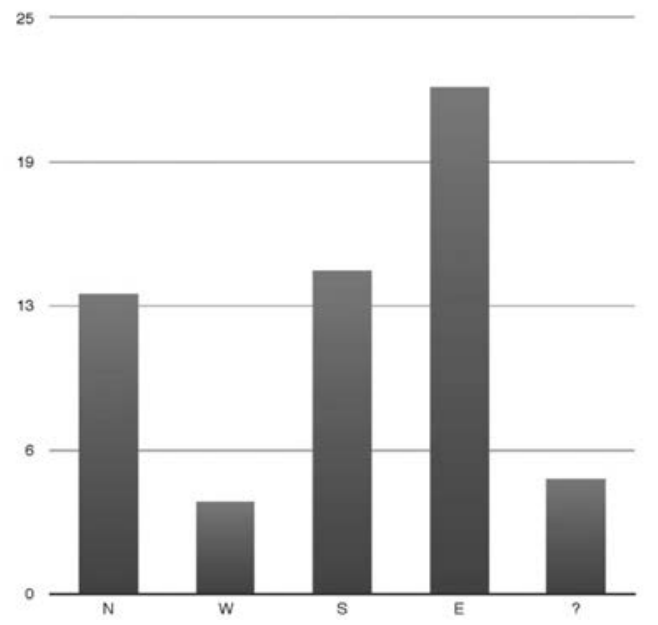

FIGURE 3. Cardinal orientation distribution of Triadic Groups. 
The chronological analysis bases on the count of Triadic Groups present within each period, that is the ones that had not been abandoned, destroyed, buried within other types of structures, or otherwise morphologically modified. In other words, the chart below (figure 4) merely shows the amount of Triadic Groups actively used at the certain timespan.

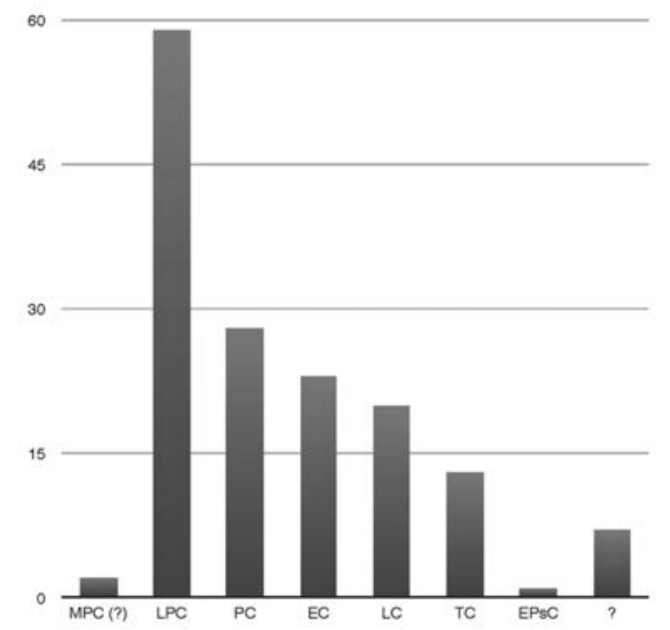

FIGURE 4. Chronological distribution of Triadics.

Temporal occurrence of Triadics follows a coherent pattern. A few issues have to be underlined, however, for this data not to be overused. As mentioned earlier, both Middle Preclassic examples have to be treated carefully, since their dating is not entirely convincing. However, even if the Xtobó Triadics are in fact rather Late than Middle Preclassic, one valuable observation was made by Anderson in connection with them:

The presence of this architectural form implies some form of architectural communication. Pottery vessels, and other portable objects ripe with symbols can be easily traded without the knowledge of what those symbols mean, but an architectural form has to be carried as a mental template. The act of specifically recreating the form suggests aknowledge of the form's significance (Anderson, 2005: 4-6).

A look at the chronological occurrence of Triadics makes the Late Preclassic period more plausible for that kind of architectural complex to be invented. A relatively sudden boom in Triadics' appearance throughout the Maya land points towards their first appearance in one of the major Preclassic centers that have been securely dated, perhaps Nakbé or Cival. Only a major political player with 
wide network of interregional connections would have been able to broadcast such a template so rapidly over an area so vast. However, quick appearance of Triadic architecture in remote Xtobó proves two important assumptions. First, an exchange of ideas among the Maya elites, that formed a crucial component of the Classic Period, had been most probably well established at the beginning of the Late Preclassic. Second, Anderson's notion of a conscious implementation of triadic form in Xtobó and its neighbors, along with an apparent suddenness of its distribution among other sites, leads to the assumption of great ideological importance of the Triadic's function and meaning. It is worth mentioning that Preclassic Triadics appear exclusively in the Lowland area, and do not occur south of the latitude of Caracol.

Overall, at least 55 Triadic Groups are being constructed at approximately 26 sites during the timespan of 500 years that constitute the Late Preclassic period (figure 5). Some sites, most notably those within the Mirador basin, feature more than one Triadic. In cases of Cerros, Nakbé, and El Mirador, these complexes "embrace" the city core, facing it from three or four cardinal directions (Hansen, 1990; Freidel, 1986). Late Preclassic Triadics always occupy prominent locations, either on elevated spots, on a side of main plaza, or as principal components of separate architectural groups. Their size, when compared with other buildings, is monumental.

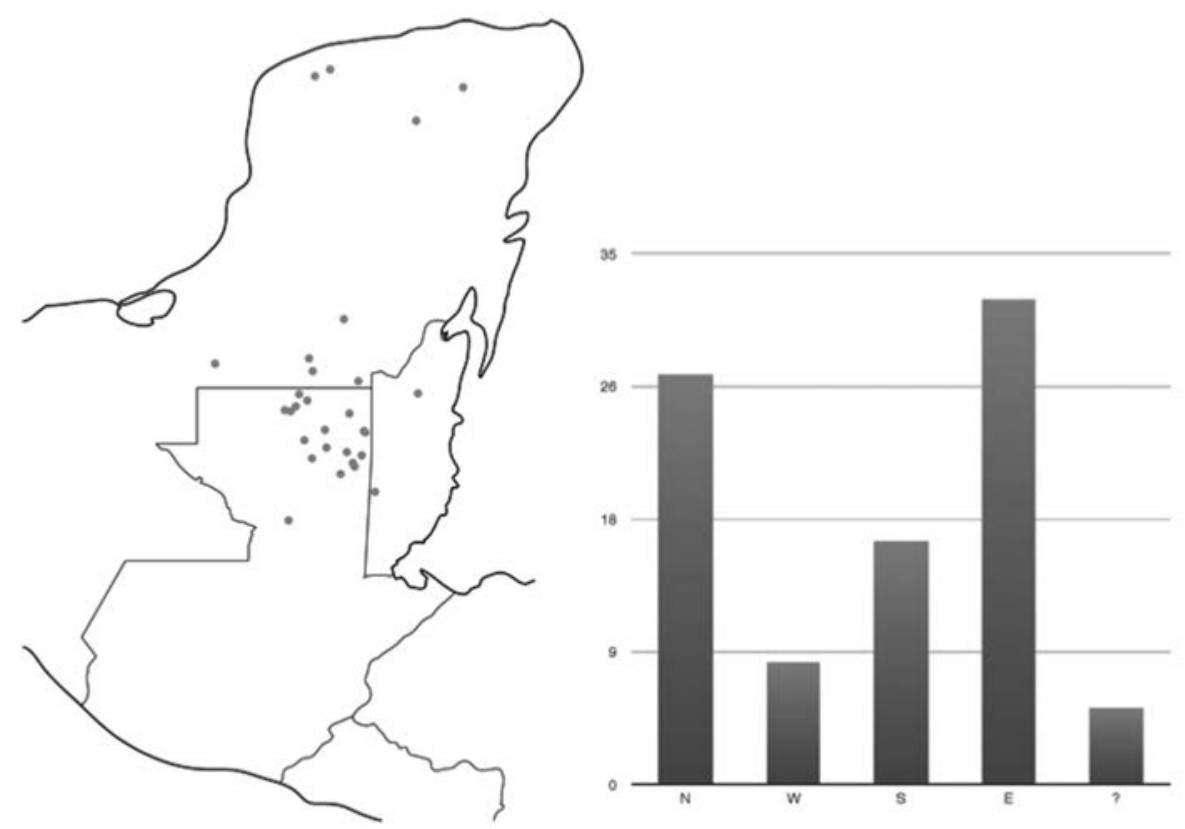

FIGURE 5. Late Preclassic distribution and cardinal orientation of Triadic Groups. 
At that time the eastern orientation prevails, reaching approximately $40 \%$ of all Late Preclassic examples, while the northern one constitutes just over one-fourth of the total number (figure 5). The southern orientation dominates on the northern Yucatán, and otherwise randomly occurs at sites such as Uaxactún, El Mirador, Calakmul, Altar de los Reyes, and Nakum. Three out of five west-oriented Triadics have been constructed at Nakbé, El Mirador, and Cerros. The other two come from Late or Terminal Classic Nakum; their shape, however, places them in the somewhat problematic U-type category that will be discussed later on (figure 1d).

Moving on from Late Preclassic to Protoclassic period a sudden drop in the number of Triadics in use can be observed. This fact has to be treated with caution, because in many sources referring to the Late Preclassic architecture, only the foundation date or period is safely established, meanwhile the abandonment of a structure cannot be properly pinpointed. Moreover, the Protoclassic Period with its transitional nature has been particularly elusive. Hence the actual number of existing Triadics after the Late Preclassic times may have been significantly higher than the one presented here. Despite this uncertainty of data, however, it can be safely stated that some sites with Triadics had been partially or completely abandoned before the onset of Protoclassic period, i.e., Nakbé. On the other hand, new Triadic Groups are being constructed at sites like El Perú and Cerros (Structure 3); the latter, though, had never been finished (Freidel, 1986).

A much more important shift in Triadics' distribution accompanies a general decline and renewal of the Maya civilization at the beginning of Classic Period. The Mirador basin ceased to be a cultural hub, meanwhile Tikal rose to a great importance. In the Holmul region a seat of power drifted gradually from Cival to Holmul, leaving the abandoned Triadic Groups behind (figure 6).

The cluster of sites featuring Triadics that appears in the eastern Petén during the Early Classic spatially overlaps with this period's political influence of Tikal. No new sites in that sphere begin to display triadic architecture, but in Uaxactún and Naranjo additional Triadic Groups are being built. Other polities preserve their Triadics already in existence, maintaining Preclassic traditions. In the K'an sphere of influence three new kingdoms feature triadic architecture, i.e., Dzibanché, Las Delicias, and distant El Perú / Waka. All four northern Yucatán sites cease to use their Triadic Groups; however, two Early Classic Triadic Groups are being raised in northeastern Yucatán —one at Tzicul and one at Ch'el. The overall number of sites featuring Triadics decreased to around fifteen, and Triadics themselves to nineteen. A virtual lack of western orientation, along with the shift from eastern to northern one as the most favored can be observed (figure 6).

The onset of the Late Classic period marks the golden era for the Maya lowland civilization. Density of settlement reaches its highest during that time, and nearly all the lowland polities are involved, one way or another, in the Calakmul-Tikal conflict. The network of exchange between elites, and, consequently, the uniformity of culture, is archaeologically attested across the Lowlands and beyond, with participants so distant from each other as Palenque in Chiapas, México, and Copán in Honduras. 


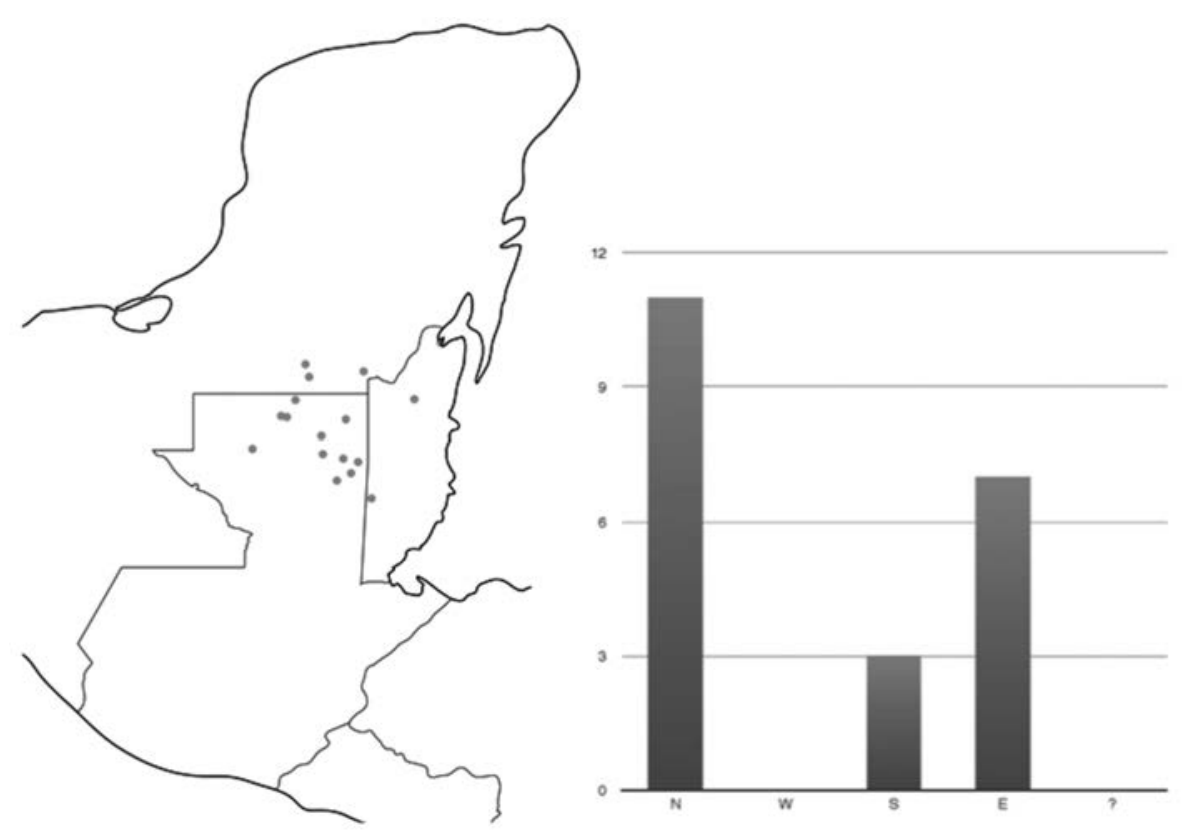

FIGURE 6. Early Classic spatial distribution and cardinal orientation of Triadic Groups.

The number of Triadics further decreases during the Late Classic. At Tikal, the North Acropolis complex no longer maintains its long-established triadic pattern, neither does Structure A-V in neighboring Uaxactún. But by no means it proves that Triadics became obsolete, for there are new Triadic Groups constructed during that period as well, i.e., Palenque's Cross Group, and Nakum Structure N, among others. It is no longer possible to establish any clusters, though, as Late Classic Triadics seem to be quite randomly dispersed over the map (figure 7). The specific case of Triángulo Park's main sites, namely Yaxhá, Nakum, and Naranjo, that not only carefully maintain their Triadics along with their surroundings, but also elevate new ones, has to be treated as a local peculiarity. At the end of Classic times Nakum enters its heyday, exercising the gap of power left after the demise of the neighboring superpowers (Źrałka, 2008; Źrałka and Hermes, 2012). It is even more clearly perceivable during the Terminal Classic period (figure 8). The northern orientation of Late Classic Triadics, similarly to the Early Classic, exceeds 50\%. The eastern one further decreases, reaching 25\% (figure 7).

During the subsequent Terminal Classic, an upsettig tie of crisis, some polities were able to delay their collapse, in fact rapidly growing during the time of a pan-regional downfall. Others, like Xunantunich, seemed to be not affected by it at all. The westernmost Maya polity of Palenque entered the Terminal Classic already seriously weakened, and fell depopulated and abandoned in the first years of 9th century (Martin and Grube, 2008: 175). 


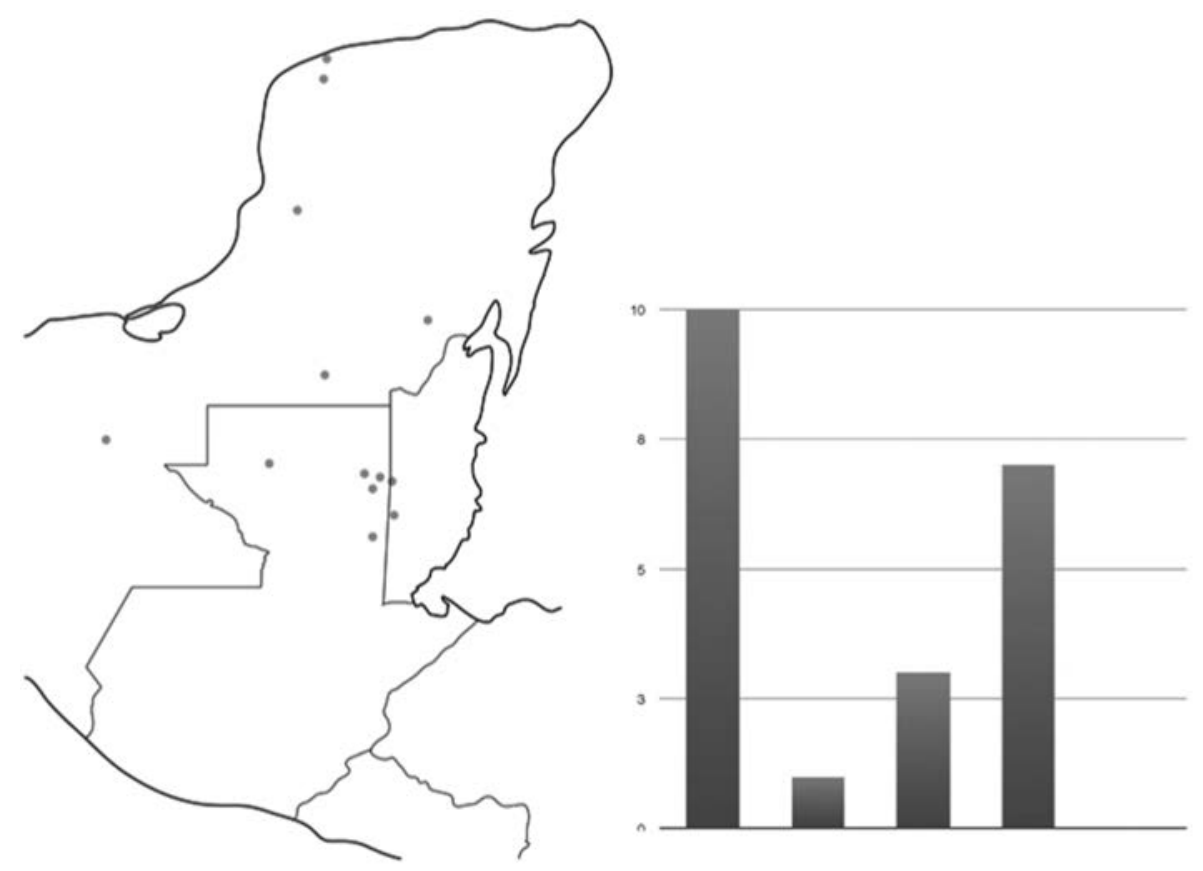

FIGURE 7. Late Classic distribution and cardinal orientation of Triadic Groups.

Distribution of Triadics during the Terminal Classic illustrates well the times of abandonment. Only a handful of sites that survived existed at that time, of which eight still featured triadic architecture (figure 8). Only three new triadic arrangements had appeared at that time, i.e., those in Nakum (Str. 99 and Str. E) and Naranjo (Str. A-15). The remaining 9 Triadic Groups are those that outlived the collapse as a remainder of the Classic Period. Again, they are most frequently oriented due north (figure 8).

Eventually all Classic sites mentioned above ceased to exist, or at least underwent modifications so extensive that Triadic patterns had disappeared from urban landscapes altogether. The Postclassic times saw a shift in population density from the Central Lowlands towards the northern and southern extremities of the Maya realm. Curiously, only one Postclassic city built a Triadic Group, that is the K'iche' capital of Utatlán (Q'umarkaj) in the eastern Highlands of Guatemala (figure 2). Archaeological reports do not mention it per se, but it can be quite easily spotted on published plans of the site (Carmack and Weeks, 1981: 328). It is somewhat removed to the east from the centre, and featuring an eastern orientation. Not much can be said about it otherwise. 

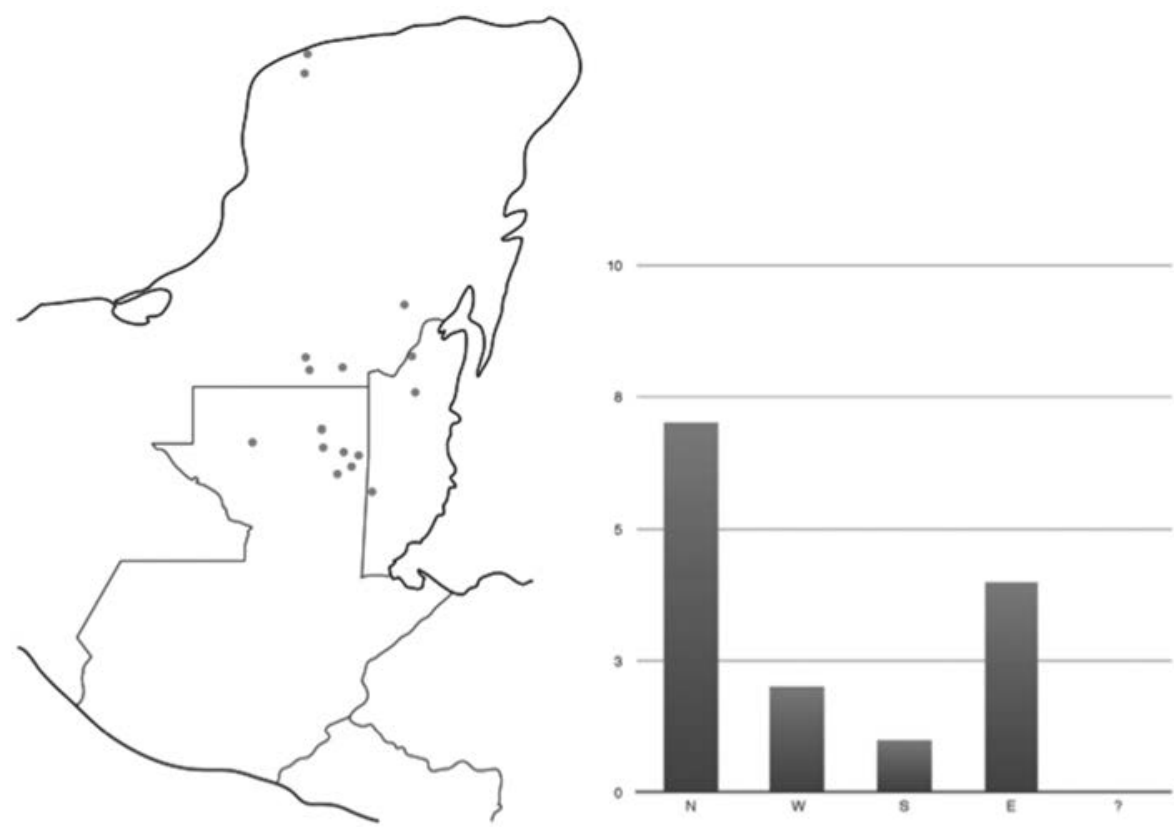

FIGURE 8. Spatial distribution and cardinal orientation of Terminal Classic Triadic Groups.

\section{Triadic Form and Its Urban Context}

Two of the earliest Triadics in the Maya Lowlands, Structure 1 at Nakbé and Triadic Group at Cival, follow quite similar patterns of development. Both cities had been long established before the onset of Late Preclassic period, having their first vestiges of architecture traced back to the Middle Preclassic (Estrada-Belli, 2011: 168-172; Hansen, 2002). At Cival the first monumental structure in the city core was a late Middle Preclassic E-Group. Sometime around the turn of $5^{\text {th }}$ and $4^{\text {th }}$ centuries, a massive Triadic platform was raised just east (or behind) of the EGroup, therefore rendering the latter obsolete. Recent excavations at the plaform have shown that the whole mass had been built as a single-episode effort, designed to be triadic in layout from the beginning. Several later phases of remodeling made the structure grow until it had reached its present height of $33 \mathrm{~m}$. Triadic pattern had been preserved throughout that time (Estrada-Belli, 2006: 64). At least since the penultimate $\left(4^{\text {th }}\right)$ constructive stage, two huge stucco masks have been adorning both sides of the stairway leading to the top of the platform (idem).

Nakbé Structure 1 was built over an earlier Middle Preclassic platform around $350 \mathrm{BC}$. It emerges as a double-stage episode, but the fully developed triadic pattern of superstructures on its top appears to be a single episode. Altogether at least seven stucco masks were adorning the entere complex. During the sub- 
sequent constructive phases the triadic form had been preserved. Just as in the case of Cival, Structure 1 eventually assumed the central position within the city core and maintained it until the abandonment of the site just before the end of Late Preclassic (Hansen, 2002). Curiously, it presents a rare western orientation, that appears elsewhere only as complimentary to other Triadic Groups within the city centers. It is quite possible, though, that at Nakbé western orientation was the earliest one.

Both Hansen and Estrada-Belli underline one peculiarity: the earliest Triadic Groups appear suddenly in fully developed form and effectively replace former focal buildings within the city centers (Hansen, 2002; Estrada-Belli, 2006: 64). In the case of Nakbé there are other Triadics that flank the site core on all the remaining sides (idem). Other early Triadic Groups also appear as single-episode constructions. However, at Cerros a sequence of construction episodes of various structures points towards a certain evolution of the triadic pattern. While the first Triadic raised at that site, Structure 6, also appears as a whole sometime during the 1 st century $\mathrm{BC}$ with stucco masks resembling those at Cival and Nakbé, slightly earlier non-triadic Structure 5 bears similar artistic program (see below). Subsequent constructive episodes bring an array of three more Triadic Groups oriented towards different cardinal directions. All of them most probably had been adorned with stucco and stone masks following the pattern of Structures 5 and 6. An apparently unfinished Structure 3 is an exception, though. Curious layout of Structure 29, however, clearly reveals a supremacy of spatial configuration over its utility and accessibility. On an elevated platform oriented towards the east a central superstructure is flanked by two long lateral ones that face each other along the north-south axis that passes almost through the middle of the main building. All three are set so close to each other that reaching either stairway of the lateral structures turns out to be nearly impossible, especially with the long-snouted decorations emerging from their facades. Freidel (1986: 11-12) underlines the importance of such a spatial template, perhaps due to its ritual meaning. The recurring set of motifs that is ascribed to masks adorning the Triadics at many sites might have been conceptually earlier than the triadic architecture that had served as its canvas, as seen on Cerros Structures 5 and 6 (see below; Freidel, 1986). Schele and Freidel also note (1990: 119-125) that the Triadic Groups at Cerros constitute anchor points for the city's layout axes, encompassing the entire site. Such an urban plan had been perhaps conceived at once, but its realization took at least two centuries (idem). It stays in concordance with an apparent urban planning in the Mirador Basin sites, where Triadics mark focal points of the centre layout (Hansen, 2002; Šprajc et al., 2009).

At Late Preclassic sites of Altar de los Reyes and Xtobó, Late Classic Palenque, and also, to some extent, Terminal Classic Nakum, Triadic Groups are set apart of the centers. The Cross Group at Palenque rises on a semi-manmade low platform beyond the edge of the main plaza, with access provided from the north, that is from outside of the centre (Cohodas, 1985: 61-62). The Maya planners of Altar de 
los Reyes actually constructed a separate group with its dominant Triadic structure nearly $1 \mathrm{~km}$ away of the city core. Triadic Group towers over the plaza formed by other structures around, and faces the direction from which one must have been approaching it coming from the centre (Šprajc, 2008: 25-32). Xtobó Triadic Groups dominate the architectural cluster at the end of a causeway leading south from the core (Anderson, 2005). In Nakum, so called Northern Sector eventually became triadic in the Terminal Classic period (Koszkul et al., 2008: 3-6; Źrałka, 2007: 6-14).

In all four cases their isolation made them stand out as prominent locations. The gigantic Danta structure from El Mirador can also be included in that list, but its mass is so overwhelming that a vast space that separates it from the rest of the city seems only natural in terms of maintaining a rhythm of interwoven built and empty space intervals. Danta Triadic is perhaps the largest single architectural complex ever built by the Maya, rising some $72 \mathrm{~m}$ above the ground level. Its basal platform (Platform 1) measures 500 × $300 \mathrm{~m}$ and bears several structures as well as entire complexes (Pava Triadic Group among others). On the eastern side, another platform set on top of Platform 1, labelled Platform 2, elevates the actual Danta Acropolis and its accompanying structures. It faces the Tigre Triadic Group that borders the main plaza on its western edge, both being oriented $5^{\circ}$ to the south from the east-west cardinal axis (Howell and Evans Copeland, 1989; Suyuc et al., 2008: 527-529).

One of the best-known Triadics from the Classic period is no doubt the Caana Acropolis from Caracol. This massive structure, nowadays over $43 \mathrm{~m}$ high and $100 \mathrm{x}$ $120 \mathrm{~m}$ at the base, is located in the heart of Group B, in the northern portion of the monumental core of the city. The name 'Caana' translates as 'The Sky Place', and was assigned to the Triadic by archaeologists as the tallest Maya building known from Belize (Chase and Chase, 1987b: 18; 1987a: 9; Martin and Grube, 2008: 93). A number of constructive stages has been determined underneath the ultimate construction, including the base of B-8 (western) temple that revealed remains of a previous construction, $4 \mathrm{~m}$ below the latest floor of B-18-1st, with the entrance doorjambs on its southern side (instead of the expected eastern one). It is quite possible, then, that the triadic paoern on the top of Caana had emerged no earlier than Late Classic times. Before it might have been an asymmetrical acropolis with two structures facing south (B-18 and B-19) and one facing west (B-20; Chase and Chase, 2001).

Three out of four Triadics at Nakum emerged as the ultimate stages of development in their respective loci. Structure 99 that proved to be an essentially Late Preclassic massive platform that received a triadic set of buildings during the Terminal Classic heyday. All three constructions were most likely made of perishable materials, possibly in wattle-and-daub technique, canvassed over low stone foundations (Koszkul et al., 2008; Źrałka et al., 2011).

Both U-Type Triadics in the Southern Sector assumed their peculiar layout after a long sequence of constructive episodes that had been radically changing 
the architectural pattern over several decades. Central building of Structure $\mathrm{N}$ was flanked by two single-chambered structures since its first stages during the Late Classic; however, at the beginning all three had been facing the same eastern direction. The 6th and 7th architectural episodes dating to the end of Late Classic and Terminal Classic, respectively, converted the plan into a Triadic that can be classified both as a T-Type and a U-Type (Źrałka, 2008: 70, Źrałka and Hermes, 2012).

The Terminal Classic version of Structure E had also concluded a sequence of Late Classic architectural stages. Before, the summit of Structure E was crowned by a single building, meanwhile its bottommost facade featured two semi-inset buildings, all three facing east. The Terminal Classic attempt to convert the structure into a Triadic had to utilize the little space that was left on the summit without a costly and time-onsuming process of enlarging the entire pyramid. Due to such inevitable condensation a U-Type structure had turned out to be apparently the only option (idem).

Quite the opposite situation occurs in Late Preclassic Tikal and Early Classic Uaxactún, where the North Acropolis and A-V group, respectively, first assume and then gradually lose their triadic patterns. Tikal Structure 5D had been an important locus prone to frequent modifications for over a millennium. At least from the Middle Preclassic period it bore one kind of construction or another, beginning with a simple round building on a modified bedrock knoll (Loten, 2007: 1-2). Subsequent Middle Preclassic and early Late Preclassic stages saw it changing both in size and layout until it reached a pattern that might have been an immediate conceptual predecessor of the Triadic. It consisted of an elevated basal platform (by then quite extensive in size) with two low superstructures symmetrically located in the middle of its length, and another large square platform behind them bearing yet another platform crowned with a masonry vaulted superstructure (ibid.: 6-9). Loten (idem) remarks that that structural pattern, although modified, had been essentially preserved through most of the remaining stages. Although it is not triadic according to the definition, i.e. the front/lateral platforms do not face each other, a triad of structures is already there. Subsequent phases convert it into a proper Triadic Group when the second terrace swallows both low platforms and two perishable structures begin to face each other on its enlarged top (ibid.: 11-3). The only aberration takes place during the Protoclassic times when the entire location gets completely encapsulated within a large, elevated, two-tiered platform (ibid.: 30). At the onset of the Classic period the triadic layout returns in its fully developed glory and scale that points to it as a primary location within Tikal. As in many other cases, the main entrance to the platform is then adorned with stucco masks, and so are both terraces of the substructure of main temple. At the front edge of the platform a gate-like structure is located, that might have served both as an architectural division of space and an accesscontrolling device, as probably in other Triadic cases as well, i.e. Uaxactún A-V and Group H, and Yaxha (Valdés, 1989; García, 2001). The whole triad reaches its 
peak development sometime before the beginning of the 5th century AD, by then functioning as a monumental necropolis of the city royal lineages. From around $400 \mathrm{AD}$ onward the actual Triadic Group gradually gets blocked by another row of temples growing in front of it, and most probably loses all its ritual importance by the beginning of the Late Classic (Martin and Grube, 2008: 43; Loten, 2007: 64-66).

Structure A-V at Uaxactún had a comparatively short history and fewer stages than its Tikal counterpart, although Valdés (1989: 37) underlines both structural and developmental similarities between these complexes. In place of a Preclassic pair of small buildings a fully developed Triadic appears at the beginning of the Classic period Tzakol 1 phase (ibid.: 32). Further development stages add more structures and elevate the platform surface but leave the triad essentially intact. A notion by Valdés (idem) that at that point the A-V might have turned from a purely ritual function into more funerary-commemorative one, just as the Tikal North Acropolis, can be justified by the number of Early Classic royal burials. However, in the author's opinion these two functions do not stand in opposition being rather complimentary to each other, especially in the Triadic context. Later chapters will focus specifically on the ritual aspects of Triadic Groups. At the turn of the Early and Late Classic periods the A-V Triadic underwent another series of profound modifications that at first left it as a U-Type triad, and then completely drowned the triadic pattern in a maze of interconnected patios and ranged buildings.

The ultimate destiny of both 5D-22 from Tikal and A-V from Uaxactún, then, turned out to be the same from the conceptual vantage point. They gradually lost their value as prominent, visually exposed loci with the triadic arrangement on their summits, either turning into other functions or falling out of the perceptual grid.

A great majority of Triadic Groups, however, shared a less complicated fate. Once they had emerged, they usually stayed more or less intact for the rest of their lifespan within urban landscapes. If modified at all, they had usually been enlarged or new embellishments had been applied to them, meanwhile the basic conceptual plan behind their function and meaning was constantly manifested in the triadic layout. It was rather the city that kept evolving around, more often than not respecting the existence of monumental Triadic Groups.

The question of architectural context of Triadics within the city canvass seems now appropriate. No obvious array of rules considering placement of Triadic loci appears from mere studying the site plans. However, some details prove to be recurring quite frequently, especially those that associate Triadic Groups with neighboring structures and natural features.

As mentioned before, the most frequent location of Triadics lies within the strict centre of a site. Many such complexes assume the principal position among other buildings, becoming focal points that tower over entire cities. Their outstanding monumentality immanently turns them into landmarks in the local skyli- 
nes, as for example in Preclassic Nakbé (Structure 1), Cival, El Mirador (Tigre), Cerros (Structure 4), Classic examples from Caracol and Calakmul (Hansen, 2002; Estrada-Belli, 2006; Hansen, 1990; Freidel, 1986; Martin and Grube, 2008; Folan et al., 1995; 2001). As a rule Triadics border extensive plazas that balance vertical mass with horizontal emptiness (Miller, 1999: 23). Quite possibly such plazas were a requirement, if the importance of triadic pattern in fact stemmed from its ritual function. Many scholars agree upon such a view of the Maya architecture as a grand religious and political stage that reinforced, restored, and recreated order, power, and the entire cosmos (Inomata, 2006). Only few exceptions to that rule exist, where Triadic Groups are squeezed in between other structures. This can be observed in Cival, where Triadic Acropolis had been fitted just at the back of the E-Group, having no immediate gathering space in front of it. However, the E-Group, which ceased to fulfill its astronomical functions due to the lack of horizon observation points blocked by the Triadic, was never demolished (EstradaBelli, 2006).

Spatial co-occurrence of Triadics and E-Groups can be further attested by urban plans of several early sites. The E-Group plaza at Uaxactún is flanked by a Triadic Group on its southern side (Ricketson and Ricketson, 1937). In the Mirador Basin, centrally located E-Groups are surrounded by Triadics, as seen in El Mirador Leon complex, with Tigre and Cutz Triadic Groups immediately to the west and east, respectively (Hansen, 1998: 80; Šprajc et al., 2009: 85). Late Classic Calakmul features a similar pattern, where the E-Group located in the middle of the main plaza is flanked by both Triadics from the north and south sides (Folan et al., 1995; 2001). A Preclassic platform under the Structure 99 in Nakum encapsulates an earlier platform with a building set far on its northern edge; such a layout evokes a possibility of two other buildings once existing on the vast space on front of it. If it had indeed had a triadic plan in the Preclassic times, it might have corresponded with an early version of Structure $X$ that is thought to be originally an E-Group (Dr. Jarosław Źrałka, personal communication, November 2013). A recent article by Flores (2010) proposed the Western E-Group -Eastern Triadic Acropolis tandem to be a standardized layout; such a notion, however, seems to be an oversimplification, applying only to the east-oriented Triadics, mostly in the Preclassic times.

Another recurring urban layout concerning Triadic Groups features a separate architectural group removed from the centre, and usually connected with it via a causeway. Such is the case in Middle or Late Preclassic Xtobó, Late Preclassic El Mirador (Danta and Pava Groups) and Altar de los Reyes (Southeast Group), Late Preclassic and Late Classic Northern Acropolis at Yaxhá, and Late Classic Kinichná Group of Dzibanché, among others (Anderson, 2005; Howell and Evans, 1989; Šprajc, 2008: 25-32; García, 2001; Nalda et al., 1994). To a certain degree, also both $\mathrm{H}$ Group Triadics in Uaxatcún, and the Cross Group in Palenque, follow the same pattern (Kovač and Arredondo, 2010; Cohodas, 1985). The reason behind such a design might have been different for each site, nevertheless it is plausible 
that the main factor was the requirement for the appropriate amount of space for a Triadic to be properly accentuated and to accommodate its ritual needs.

A peculiar observation was made by Fialko (2004) in connection with the Triadic Groups at Naranjo. At least four such complexes have been located in the immediate vicinity of caves (ibid.: 574). In the case of Structure B-5 the cave entrance lies in front of the Triadic Group's monumental stairway. This notion evokes another, similarly interesting feature from El Mirador. On the summit of the first basal platform that bears both Danta and Pava acropoleis a large circular depression had been discovered, measuring roughly 50-60 m in diameter. It was never definitely determined whether the basin was man-made or natural, but its regular shape points toward the former (Howell and Evans Copeland, 1989: 8). The pattern of such a Triadic-and-cave/basin pairing occurring at both sites can hardly be a coincidence. Cavities of any kind had a strong supernatural significance in Mesoamerica at least since the times of Olmec culture that flourished in Veracruz and Tabasco states in Mexico during the Early and Middle Preclassic periods (Brady and Prufer, 2010; Grove, 1970). Findings at Chalcatzingo (Aviles, 2000), and under the Pyramid of the Sun at Teotihuacan (Taube, 1986) revealed that caves had been perceived as places of origin, power sources, and loci of passage to the supernatural realms. The Maya were no different from other Mesoamerican peoples, and their ritual cave use had been quite extensively interpreted as the important locus in rituals and power propaganda as well (Vogt and Stuart, 2010). In such a context the presence of caves in proximity of Triadic Groups would attest to their meanings as being intertwined.

\section{Iconographic and Epigraphic Programs of Triadic Groups}

Analyzing a mere form of a building, it is possible to determine its function only to a certain extent. The meaning can be even more elusive, making it virtually impossible to reconstruct perception of particular spaces by their ancient creators focusing solely on architectural morphology. Triadic Groups, however, quite often appear to be architectural canvasses for artistic media, especially during Preclassic times. Moreover, artistic programs displayed on them present a rather uniform set of features that sheds some light upon our understanding of their designers' purposes and intentions.

The majority of Preclassic Triadic Groups that have been excavated feature large stucco masks on their facades, sometimes over a meter in height, and several meters in length. Most frequently they occur on frontal sloping facades, or taludes, of basal platforms bearing a triadic arrangement, on both sides of their monumental stairways. In case of 2-Tiered Triadics another favored location seems to be on the facades of particular substructures of the triad. All stucco friezes discovered within the Triadic Groups bear striking resemblance to one another, to the point that they might be plausibly treated as a standard decoration 
linked to the function and meaning of Triadics as a genre ( $c f$. Freidel, 1986; Freidel et al., 2002; Estrada-Belli, 2006; Kovač and Arredondo, 2010).

Chronologically first monumental stucco masks discovered within Triadic Groups come from two regions within the Maya heartland of the Guatemalan Petén department — the Mirador Basin, and the Holmul region. The site of Nakbé features several Triadic Complexes, of which of particular interest are Structure 1 and Structure 27. The first is the largest construction at the site, meanwhile the other is the tallest. Both display multiple large stucco masks that depict huge anthropomorphic faces. Structure 1 features five such friezes: two pairs flanking the stairway from the platform to the summit of the central structure, and one additional mask on the northern building (Hansen, 2002). Structure 27 was decorated with a pair of masks on its main building (Forsyth and Acevedo, 1994). In both cases the preservation of stucco was poor. Not much has been said about the masks' iconography otherwise; however, a number of common elements are clearly visible. Each mask features a stylized face with a pair of large circular earplugs or ear-flares flanking squarish rounded eyes and pronounced zygomati bones. Upper parts of an open maw are still preserved, along with long snouts or trunks emerging from the central portions of each face (Hansen, 2002).

At the grand site of El Mirador a few dozen of Triadics have been reported (Hansen, 1998). Of great interest for this paper are buildings known as Structure 34, Danta, and Pava complexes. On these, the stucco masks had survived until modern times, and have been mostly restored, analyzed, and interpreted. The Pava Triadic Group presents vestiges of stucco masks on its central and eastern structure. Whether the western structure once featured friezes has yet to be determined, but it appears that it underwent at least one major remodeling episode during the Late Classic, during which earlier decorations might have been removed. The eastern structure (Str. 2A6-6) displays two pairs of masks adorning both sides of the stairway. The upper ones were probably chronologically later than the bottom ones, possibly overlapping them during the final Preclassic stage of development. Today they are virtually nonexistent, nevertheless the lower pair of masks survived underneath. They are essentially identical, and feature an anthropomorphic face with a prolonged flat nose or beak, oval eyes, and large round earplugs with knots over their upper rims. According to Suyuc Ley and his colleagues (Suyuc et al., 2008: 527) they may represent either a stylized form of the Principal Bird Deity (PBD), Itzamnaaj, or the Maize God. Poor preservation of the central Pava structure (2A6-3) does not allow to plausibly reconstruct the masks; however, the retrieved elements feature some zoomorphic and anthropomorphic details (idem).

A quite similar pattern of mask preservation occurs on the Danta Triadic. The northern (to the left from the center) structure, labelled 3A8-1, features large stucco masks in fairly good shape that feature similar knots and ear-flares. The central Danta structure, or 3A8-2, also possessed stucco masks on its bottommost platform. However, due to some Late Classic construction activity at the bottom of 
the substructure they have been mostly destroyed (Suyuc et al., 2008: 528). The retrieved elements feature emerging upper jawbones, zygomatic bones, long snouts or beaks, and other anthropomorphic and zoomorphic details (idem).

Structure 34 from El Mirador, along with two small buildings labelled 33 and 35, forms a Triadic Group that flanks the gigantic Tigre pyramid from the south. The central building (Structure 34 itself) bears a pair of friezes that feature the same set of iconographic details as the ones from the Danta and Pava acropolises, accompanied by enormous jaguar paws. Also the eastern (leftmost) building of the triad has recently proved to be flanked by similar masks (Hansen et al., 2005). Other Triadic groups at the site also appear to feature stucco masks, however their poor state of preservation and lack of data does not allow the iconographic analysis (Suyuc and Hansen, 2006).

The Late Preclassic stucco masks that adorn both Triadic Groups at Uaxactún Group H were first excavated during the 1980s (Valdés, 1986; Freidel et al., 1993: 139-143) and recently by the ongoing Slovak SAHI archaeological project since 2009 (Kovač and Arredondo, 2010). In each case they flank the broad monumental stairways that lead to the summit of the Triadic platforms.

The southern H Group Triadic Group is a model example of Fractal-Type triads. A large platform oriented to the east bears three substructures that form a triadic pattern; the central substructure, labelled $\mathrm{H}-\mathrm{X}$, further displays a triadic layout formed by structures Sub-3 (main), Sub-4 (north), and Sub-5 (south). Other buildings stand at the summit as well, of which a gate-like Structure Sub-10 that guards the frontal edge of $\mathrm{H}-\mathrm{X}$ is worth mentioning.

The total of at least 14 large stucco masks have been recovered during the excavations of the H-X Triadic. A pair of gigantic anthropomorphic masks flank the main entrance to the platform, measuring approximately $4 \mathrm{~m}$ in height, and over $7 \mathrm{~m}$ in length. They feature two faces with long noses and square, crossed eyes. Pairs of earplugs flank the faces, having knots attached below and on top of them. The figures also wear headbands, most likely with depictions of the Jester God (Valdes, 1986).

The gate structure, or Sub-10, was originally richly decorated with stucco heads at the bottom, and full figures on the walls. Freidel, Schele, and Parker (1993: 140-142) identify it as a popol nah, or a council house, due to its wall decoration in form of a mat - symbol of power and rulership among the Maya. The bottom friezes depict blunt-nosed jaguars wearing ear-flares with pairs of trilobed, downward facing elements hanging from them (Valdés, 1986).

Lateral structures of the triad, Sub-4 and Sub-5, featured symmetrical pairs of masks on each side of their stairways. The masks were nearly identical, differing in a few crucial details, though. Both represented long-snouted, jaguar-like creatures with round earplugs. The pair to the south (Sub-5), however, has rounded eyes with concentric circles for pupils, and does not feature lower jaws, therefore most probably depicting an Underworld deity. The northern pair (Sub-4), on the other hand, features square eyes associated with the Sun god (Valdés, 1986). 
The central structure of Triadic Group, H-Sub-3, featured four masks, two on each level of the two-tiered platform, on both sides of the stairway. They feature stylized Witz-monsters, depicting the Earth or Primordial Mountain. The lower pair displays some aquatic motifs in the form of fish and water swirls, meanwhile the upper masks are embraced by double-headed Vision Serpents, that symbolically connect the natural and supernatural realms (Schele and Freidel, 1990: 137-139).

The Northern Group H Triadic has just recently been excavated by the SAHI Archaeological Project from Bratislava, Slovakia. One of the first discoveries made upon commencing was a pair of enormous stucco masks decorating the front of the Triadic platform. They measure as much as $20 \mathrm{~m}$ in length, and originally were probably extending to the upper edge of the platform $4 \mathrm{~m}$ above the plaza level; present height, though, barely exceeds $3 \mathrm{~m}$. Nevertheless, they are most probably the largest and longest stucco friezes ever discovered in Mesoamerica (Kovač and Arredondo, 2010: 419). The masks are shaped in the form of the Witzmonster with some Jester God implementations, again flanked by large ear-flares with knots; hence tentative reading of the whole as "The Mountain of Jester God" was proposed (ibid.: 438).

Some remains of other stucco friezes had been found on upper terraces of the central building of Triadic Group (Martin Hanuš, personal communication, April 2011). Their state of preservation does not permit any iconographic analysis, though.

Among the best known triadic structures with monumental art are those from Cerros, Belize. Two of them had been once adorned with artistic programs that can still be read nowadays, i.e., Structures 6 and 29; peculiarly, chronologically the first structure bearing stucco masks that had been later copied on Structure 6, is a non-triadic complex named Structure 5. It was most likely the first monumental building raised at Cerros, and its decoration resembles the worse preserved one on Structure 6 to the point that Freidel (1986) analyzed the latter using mostly the data obtained from the former. Both structures have been oriented to the north, sitting almost on the summit of a natural hill overlooking the Corozal Bay. Radiocarbon samples place Structure 6 construction sometime between $50 \mathrm{BC}$ and the turn of eras (Walker, 2005: 25). A focal point of that group is a two-tiered pyramidal platform, 6B that probably bore a perishable superstructure. The facades of these terraces were decorated with large stucco masks featuring polimorph heads interpreted by Schele and Freidel (1990: 20-22), as double incarnations of the sun (lower facade) and Venus (upper facade), in their morning and evening aspects, on the right (eastern) and left (western) sides, respectively.

Basal platform of the entire complex, $6 \mathrm{~A}$, was crowned by additional structures, among them two asymmetrical side platforms, 6D and 6C. Three other mounds were set on the southern edge of the platform, perhaps as architectural means of access control (Walker, 2005: 21). The same pattern may be observed 
in other Triadic Groups from the Late Preclassic (cf. Uaxactún Group H Triadics above, and Yaxhá Triadic Acropolis and Cival Structure 1 below).

The interpretation of Structure 6's friezes is based on a similar iconographic program found on Structure 5. It is earlier and smaller, and does not feature the triadic pattern; however, its stucco decoration survived in good condition until modern times. Initially, Freidel proposed a two-level interpretation of the frieze, according to which four masks had reflected the daily path of the Sun and appearances of Venus as Morning and Evening star, at the same time representing Hunahpú and Xbalanqué (Schele and Freidel, 1990: 104-116; Christenson, 2007). However, over a decade later, a more thorough identification of particular elements omposing the frieze led Freidel and colleagues to diferent conclusions. They made an observation that the upper tier masks display some avian features, meanwhile the lower tier features the feline ones. A peculiar argument has been made according to the ear-flare depiction. First of all, the shape of its oval element strongly resembles the Maya glyph for beh or b'ih, a word that means "road" or "path". Secondly, the volutes surmounting each ear-flare, formerly identified with K'awiil, now have been thought to represent a stingray perforator and a swirl of blood (Freidel et al., 2002: 63). Yet again three years after the second interpretation Freidel (2005) announces another explanation of the whole $5 \mathrm{C}-2$ nd decoration:

Today I think the lower masks represent funerary masks of the bundled bones of the Maize God and his twin brother. The upper masks represent ltzamnaaj and Chahk, the axe-wielding sacrificer god; these creator gods caused the death and resurrection of the Maize God. These were the gods impersonated by the king when he performed here as a lord of creation (ibid.: 53).

One way or another, each of these interpretations tackle the same ritual theme, that is the creation of the world. The metaphors proposed by scholars differ from one another, though, and so do the actors, at least at first glance. Of particular interest is the fact that the iconographic motifs such as ear-flares, knots, and trilobate pendants occur on the majority of presented examples from all over the Lowlands.

Contributing to the collection is one of the most recently discovered stucco friezes that adorned the Triadics. It comes from Cival Triadic Group Structure 1, where it once flanked the stairway to the main building. The Cival frieze consists of two masks located on the highest terrace of the central substructure (EstradaBelli, 2006: 68). A group of diagnostic details has been selected by Estrada-Belli that helped to identify both depicted personages, and also hinted the function and meaning of the whole structure. This array consists of L-shaped eyes, flame eyebrows, pug noses, crossed bands, ear-flares with swirls and knots, J-shaped fangs, U-shaped molars, upturned exclamation marks, wrinkles, lack of lower jaws, and the paw-wing motif, among other things (ibid.: 65). The same set of 
details, more or less complete, can be observed in most of the Triadics' stucco decoration. The Cival masks, however, most accurately resemble the lower tier of 5C-2nd decoration at Cerros, albeit the former is at least two centuries older than the latter, with charcoal pieces obtained from the stucco yielding calibrated dates around $200 \mathrm{BC}$ (idem).

Upon analysis, each of the motifs distinguished by Estrada-Belli pointed towards a Middle Preclassic pan-Mesoamerican iconographic tradition, stemming mostly from the Olmec art. Especially appealing is the masks identification with Tzuc, a word that denominates a metaphysical concept and a divine being at the same time. Using a simplified definition, Tzuc is a trinity of gods acting as one, that reside (or impersonate) the centre of the Sky, its navel, or the primordial Heart of Creation. This location, known from Popol Vuh, became a birthplace of various gods, and directly led to the creation of the Universe, and indirectly to the appearance of the Maize God, and, in consequence, the human race (ibid.: 71, Christenson, 2007). Overlapping identifications of diffrent beings led Estrada-Belli to a conclusion that the friezes at Cival depict a conflation of Chahk, Maize God, Palenque Triad God I, Sun God/Tzuc, and the Olmec Avian Serpent and God I. The whole group represents the beginning of the world with all its beings, glorifying its true creators (Estrada-Belli, 2006: 71-73).

Structure 1 at El Tigre/Itzamkanac, although not a Triadic in its ultimate stage of development, might have once been one. The remains of one lateral platform located on the summit terrace of Structure 1 summit just west of the main building, along with a vast unoccupied space on the opposite edge, allow to assume a triadic pattern in earlier Late Preclassic stages of development. A rich decoration program of Structure 1 survived mostly in terms of a frieze that adorned the stairway in the Late Preclassic period. The central face of the mask has been identified as a reptile, perhaps an iguana (Vargas and Delgado, 2003: 991). The ornaments and details, however, bear striking resemblance to stucco friezes from Uaxactún, Cerros, and Cival. The presence of ear-flares with knots and swirls, paw-wing, and perhaps flame brows, is apparent even on a highly stylized reconstruction drawing, and therefore places the mask at the same interpretation level with Cival masks.

Another stucco mask that bears some reptilian features comes from Early Classic Lamanai. Here Triadic Structure N9-56 yielded two pairs of masks, again flanking the stairway. The upper masks did not survive the Late Classic remodeling episodes, meanwhile the lower ones have been thoroughly buried within the rubble. The southern mask represents a young male with upturned upper lip and two enormous ear-flares. The whole scene is surrounded by swirls, perhaps depicting smoke or water. The headdress adorning forehead of the figure has been partially destroyed, but it features strong reptilian nuances that led scholars to believe that perhaps a crocodile or other large reptile used to be worshipped in Lamanai. The name itself, being reconstructed as Lama'anayin, would attest to such a theory (Pendergast, 1981: 37-38). According to Estrada-Belli (2006: 68) 
reptilian features denote the Olmec God I, as seen on the Olmec examples found on various portable objects from coastal México. God I constitutes an Olmec counterpart of the Maya Earth Monster, that is a supernatural that personifies both the surface of the Earth and the entrance to the Underworld (Pool, 2007: 117).

Many other Preclassic and Early Classic Triadic Groups appear to have been adorned with stucco friezes, albeit some of them perceptible only in vestiges of stone armatures, or just in the lime mortar pieces found in the rubble. However, the Late Classic Cross Group at Palenque yields a complete and fully intelligible artistic program that has also been interpreted as a key to understanding the Triadic function and meaning. Although the whole group adjoins the main plaza with its western edge, the access is provided from the southern side, making it stand out as an isolated architectural complex. It consists of a low, semi-natural platform oriented to the north. The most important artistic program has been found within inner sanctuaries called pibnaahob, located inside the three temples. A sequence of scenes depicted on the panels operates on two intertwined levels. On the literal level it reports a series of actual, historic events connected with Kan Bahlam's accession to the throne, that included dedicatory activities, ritual bloodletting, heir designation, and again bloodletting and accession rituals (Hansen, 1998: 80). Artistic decoration of the Cross Group at Palenque is worth a closer look for one more reason: this site has been an eponymic home of the Palenque Triad, a group of gods known from other sites as well, but only here worshipped together (Miller and Taube, 1993: 129-130). They have been labelled as GI, GII, and GIII by Heinrich Berlin in 1963, and until today their proper Mayan names still remain obscure. Some remarks can be found on the Cross Group panels that concern the Triad's birth dates. The oldest of the three is $\mathrm{GI}$, born in $3122 \mathrm{BC}$, that is just prior to the current world creation $(3114 \mathrm{BC})$. However, he has been named both the father and son, and TC yields just one more birth date of GI placed in $2360 \mathrm{BC}$, so already during the current era. It led some scholars to believe that under the label of GI there are two related deities, father and son, sharing the same name (Loundsbury, 1980). The newest study of the Palenque Triad, however, proposes an entirely different interpretation of Gl's identity. Stuart (2005: 170-174) reads the sequence of important dates from GI life stages as concerning the same deity. His second "birth" might have been only a descent from heavenly realms onto earth as a metaphor of transformation from a universal god of creation to a more localized Palenque form of the same entity.

GII, the youngest of the Triad, was born 18 days after GI, of the same mother, as stated on the TFC panel. This deity is well known from Maya religion under a variety of names: God K, Tohil, K'awiil, or Manikin Scepter. Judging by his iconographic depictions, he is very small, and often figures as an effigy carried in the crook of the ruler's arm. He has been interpreted as a patron god of the ruling families as well as a god of lightning, again being connected to Chahk (Miller and Taube, 1993: 130). 
The middle brother, GIII is the main subject of TS decorations. Born 14 days before GII and 4 days after $\mathrm{GI}$, he can be clearly linked with K'inich Ajaw, or the Maya Sun God. On TS panels, however, he takes form as the Jaguar God of the Underworld, which might represent the path of the Sun during the night. Taube proposes the interpretation of GIII as both diurnal and nocturnal aspects of the Sun (Lounsbury, 1980; Miller and Taube, 1993: 130).

The array of themes featured on various Triadic Groups decorations does not reveal one definite function and meaning of this kind of architecture. However, the frequency and recurrence of some motifs allows to narrow down the spectrum of cultural traits that may be linked to the Triadics. Generally, stucco masks tend to occur on the front sloping facades of basal platforms, flanking a central, monumental stairway. Some 2-Tiered Triadics display vestiges of stucco friezes on frontal facades of particular substructures forming the triad. Friezes within each Triadic Group are symmetrical in size and overall shape, albeit differ from one another in crucial details.

\section{What Does, and What Does Not Fit the Triadic Layout?}

Some two decades ago, Linda Schele and David Freidel proposed an interpretation of Triadics as monumental reflections of the Cosmic Hearth. The Cosmic Hearth is an allusion to the Creation event, and Schele and Friedel's interpretation of Triadics as such was further enforced by identifying stucco friezes from Group H-South at Uaxactún as Tzuc, which is understood literally as the "partitioning of the universe and emergence of the first land" (Freidel et al., 1993: 140). This interpretation however, was later somewhat flattened, repeatedly stressing the Cosmic Hearth portion while ignoring the other half regarding the partitioning of the universe (Taube, 1998: 468; Hansen, 1998: 80).

The idea of replicating an important celestial constellation in an architectural pattern is indeed very tempting, but two formal features of the Triadic layout contradict such an interpretation to a certain degree. First, the southern portion of the Orion constellation, known to the Maya as the Celestial Hearth, moves through the nightly sky, but never rotates, that is, never changes its orientation in relation to the cardinal directions and thus always points towards north and opens due south (Aveni, 2001: 44, 58). When necessary, the Maya builders could, and have, oriented the important structures very nearly towards the desired directions, as for example the E-Group complexes (Aveni et al., 2003). As was shown at the beginning of this paper (figure 3), the Maya Triadic Groups were oriented towards all cardinal directions, with the east being most favoured in general. It is hard to imagine that a monumental building thought to be mirroring certain celestial figures would have been constructed with a disregard to the original feature. It has to be noted, however, that in the course of centuries a shift in favoured orientation from the east to the north can be observed. That being 
said, no period of development of Maya culture saw Triadics oriented exclusively towards any single direction.

The second feature that contradicts the Triadics' identification with the Celestial Hearth is the inequality of height within the Triadic arrangement. The Hearth on the sky, mythologically one of the first loci that ever existed, which was subsequently reproduced within each household, is in fact conceptually secondary to the domestic fireplace. Quite obviously, all the cultures in the past were explaining natural phenomena by means of parallels to objects and activities from their daily lives. The invention or introduction of pottery to Maya culture in the Early Preclassic times resulted in changes in cooking technology from putting hot stones within a vessel full of liquid to the more efficient and versatile way of placing a vessel directly over fire. This was not previously possible with preceramic gourd vessels, and now required a device to hold the vessel in place. Three stones of approximately equal size placed around the bonfire served this purpose just right. Four stones would be an unnecessary effort plus they would have to be exactly similar to prevent pots from rocking. Until today three-stone hearths mark the centre of contemporary Maya kitchens.

With such an object close at hand in every Maya house, immanently present in both daily life and the cultural conscience, the three distinctive, equally bright stars on the sky had been associated with the hearth. Thus if the ancient Maya ever intended to re-reproduce the hearth in the form of monumental architecture, they would have most probably used a layout of three equally high structures arranged at the corners of an equilateral triangle. However, Triadic Groups feature the central substructure significantly higher than the lateral ones, and in many cases this disproportion exceeds mere aesthetic or constructive concerns. Such a form was designed to reflect a cultural motif of three elements, in which two are equal, and the third one is more prominent or important.

In his discussion about the Triadic arrangement at Palenque Cross Group, Hansen (1998: 80) notes that the inscriptions found within each structure attests to the structure's function as housing the gods of creation. As a matter of fact the Cross Group is unique in terms of the modern understanding of its ritual function, the exact date of its dedication, and its commissioner (Marc Zender, personal communication, December 2012). Hansen extends that identification, as the representative example, over the whole genre of Triadic architecture:

The specialized events that occurred during the accession of Kan Balam included dedication and ritual activities (Cross), bloodletting (Sun), heir designation ceremonies (Sun), and bloodletting and accession rituals (Foliated Cross). The peculiar order and placement of the events recorded at Palenque suggest the possibility that the triad may have been a standardized format for important religious and ideological rituals (...). The continuity of the triadic arrangement may indicate the antiquity of accession rituals and bloodledng rituals in the lowlands (Hansen, 1998: 80). 
This statement, although not improbable, may be a long shot that cannot be easily corroborated. The Cross Group, one of the latest Triadic Groups constructed by the ancient Maya, had certainly been designed to accommodate ancient traditions and ritual concepts recurring in the Maya culture already for more than a millennium. However, the entire site of Palenque is widely recognized as having its local version of myths and pantheon of gods, and a specific way of conducting the rituals. Despite their presence across the Maya world, these local deities and rituals presented a fusion of pan-Maya and local motifs with the importance of particular personages structured differently. A number of other lowland Maya sites provide information about such localized groups of patron gods, and region-specific ritual activities aoested in the archaeological material (Taube, 2006: 265-266). The unique set of inscriptions recovered from the Cross Group may be explained by the randomness of archaeological discoveries as well as by its localized nature.

Moreover, one of the most accentuated cultural features of the Late Classic Lowland Maya was the artistic and ritual focus on the ruler and his personal aggrandizement. It is thus plausible that it was Kan Bahlam's intention to merge the monuments commemorating his accession to the rulership with a broader, central topos of a great cultural importance, further enforcing his divine right to preside over his kingdom. Extending that function of the Cross Group over the Preclassic Triadic Groups faces a basic difficulty of knowing frustratingly liole about the Preclassic rulership. Far from being firmly grasped, the modern understanding of social structure before the Classic period is based on a continuously growing data set. Nevertheless, the perception of the king and his place among his subjects in the Preclassic remains elusive. No evidence of accession rituals have been recovered from Preclassic Triadic Groups.

An array of cultural traits concerning the Triadics has led multiple scholars to link these architectural compounds to the Creation event. Although analyzing different kinds of data and using different perspectives and lines of reasoning, they all eventually arrived at various aspects of the Maya Genesis as underlying the construction of Triadic Groups (Freidel et al. 1993; Schele and Freidel, 1990; Taube, 1998; Hansen, 1998; Estrada-Belli, 2006). Indeed, the ubiquity of triadic arrangements, and their cultural endurance, must have been a reflection of some central and basic ideological idea that had never fundamentally changed despite civilizational evolution. However, the Maya had never formed a unified political institution, nor did they possessed a single canonical "gospel", or uniform standardized religion. Instead, Maya pantheon consisted of multiple beings with variable sets of aoributes and fields of operation that frequently overlapped and conflated into each other (Vail, 2000: 123). Despite a general sense of coherence, the myths describing the emergence of gods, their interactions and activities that led to the creation of the world, present the same variety. The Creation myth itself was regularly described as a multi-stage process featuring a number of actors (Wagner, 2006). 
A very powerful topos of three elements that no doubt belonged to the very core of the Maya beliefs can be actually divided into two events from the Maize God's life. Most of the versions of the Creation story hinge on the Maize God's sacrifice, journey through the Underworld, and resurrection. These scenes have been routinely captured by Maya artists in the threefold layouts of the Maize God himself, and two other personages that witnessed or facilitated his endeavors.

In the journey scenes the Maize God is most frequently depicted in a dugout canoe floating among the watery Underworld. Paddler Gods navigate the vessel helping the Maize God to get to the surface world. They are opposing beings of day and night, or light and darkness, with feline and solar features. In the Postclassic Popol Vuh version of this event, the Hero Twins bring their father's head back from Xibalbá to revive it. They also feature feline and solar elements, and have been identified with the Sun and Venus. No clear connection between the Paddlers and Hero Twins has been established, though. Nevertheless, this pairing of motifs stands in accordance with elements of the stucco friezes found on many Triadic facades, that also feature jaguar and solar symbols, as in Cerros, Uaxactún Group H, Nakbé, El Mirador, and Cival, among others (Freidel et al. 2002; Valdés, 1986; Hansen, 2002; Estrada-Belli, 2006). As some scholars have pointed out, the Uaxactún H Group stucco masks bear some aquatic symbols (Saturno et al. 2005).

The overall template of the journey scene, with the Maize God in the centre, flanked by two minor personages, is similar to visual design of triadic architecture. However, the artistic programs of Triadic Groups frequently present witz iconography that cannot be easily fioed in the journey story (Kovač and Arredondo, 2010; Freidel et al.: 1993). Additionally, there are other, emic concerns that present some difficulties in linking that event with the Triadics (see below).

The ultimate mythological scene concerning the Maize God is his resurrection. This joyful and glorious moment is loaded with positive emotions and profound, multi-layered metaphors from earthly life and royal ethos. After being planted and hidden from sight for a time being, maize grows out of the ground, at the same time causing relief and marking the beginning of another cycle of hard work with harvesting and processing corn cobs. A number of Classic Maya kings had commissioned their post-mortem depictions in disguise of the Maize God returning from the dead. Such messages are easy to read and understand: although already divine, Maya kings had been assuring their resurrection and heavenly immortality by the unification, or impersonation of the Maize God. On the mythological level the maize plant is especially important, for it is the very substance of creation. After two imperfect attempts to build human beings that would worship the gods, they succeeded in this enterprise when using maize dough for the human flesh (Christenson, 2007: 182-83). But before it could happen, the Maize God had to return back to the surface of Earth. He did so with the help of the Paddlers at first, but then two other personages witnessed the moment of his resurrection. The most frequent pair of witnesses are the Hero Twins, sometimes bearing gourds full of water and bags of maize seeds that will be used in germination 
of life. Other versions of the story place aquatic gods, Chahk and the Terrestrial Water God, on both sides of the dancing Maize God, perhaps to provide him with water essential in his further existence. According to some scholars, this pair of attendants may also be identified as the Sun and Rain Gods that stand for two necessary elements for the growth of Maize (Estrada-Belli, 2006: 62). Usually the act of resurrection and reappearance happens through a crack on a turtle shell. This turtle has been identified as the world, and the crack as a cave that links the Underworld with the surface.

When analyzing details of the resurrection scenes, Taube and colleagues (Saturno et al. 2005; Taube, 2004) arrived at a conclusion that it had happened in a certain mythic place called the Flower Mountain. According to an extensive corpus of examples gathered by Taube, the ancient Maya believed in a paradisiacal locus of abundance, filled with fragrant air emitted by flowers and edible fruits, and inhabited by wild creatures. Most frequently, the animals depicted in association with Flower Mountain are jaguars and serpents, sometimes also a bird, a fish, and a deer. In the Popol Vuh, the discovery of that place by animal scouts happened just before the creation of humans. In fact, the discovery of maize was also made there, in the place of "Paxil" and "Kayala". That dual name might be understood as a description, for paxil refers to "splidng" or "cleft", and k'ayala' stands for "bitter water" that by extension is associated with salty sea water (Christenson, 2007:180181). Broken, split, or cleft mountain has long been linked with the birthplace of maize and the Maize God himself across Mesoamerica at least from Olmec times. Early Maize God depictions from La Venta and elsewhere show the distinctive cleft feature, interpreted by Taube as the split earth out of which the plant emerges (Taube, 1996: 41). The split is also associated with a cave within the mountain, as a passage between the Underworld and the human world.

The kayala part of the name associates the Flower Mountain with the primordial ocean that had existed before the world appeared. The first dry land emerging from it was exactly that mountain, filled with pleasant and useful objects (Taube, 2004: 80-84). The importance and ancient origin of that ideological complex is attested by its ubiquity in Mesoamerica, for traces of it might be found in Teotihuacan, Tlaxcala, Toltec imagery, the American Southwest, and the Late Postclassic Aztec and Chichén Itzá visual and textual data (idem). Its cultural provenience cannot be securely asserted, but its earliest explicit appearance on the Late Preclassic San Bartolo murals, Kaminaljuyú vessel, and perhaps on the Southern H-Group Triadic at Uaxactún, might place the Maya as the inventors and distributors of that myth among other Mesoamerican cultures (Taube, 2004: 88; Saturno et al. 2005). Contrary to this opinion, some scholars opt for Teotihuacan as the place of origin of the Flower Mountain concept. It is perhaps no coincidence that in Teotihuacan tradition a tripartite worldview and trinities of all sorts are at least as prominent as they are within the Maya culture. Moreover, the only Mesoamerican examples of the architectural triadic layout from outside of the Maya area, albeit very few, come from the Teotihuacano culture, but have been 
tentatively interpreted as reflections of a threefold partition of society rather than religious concepts (Headrick, 2007: 103-105).

Flower Mountain in the Maya thought was not only the place of heavenly abundance, but also home to many wild creatures, the birthplace of maize, and the locus of ascent of gods to the celestial realms, linking the earth and heaven. The cave piercing its base further extended that passage towards the Underworld, thus connecting all three dimensions together. As such, the Mountain became yet another representation of axis mundi, the navel of the world (idem).

The iconographic set of motifs constituting the Flower Mountain perfectly overlaps the one of the Triadic artistic decorations. First of all, stucco friezes adorning the facades of basal platforms frequently feature the witz monsters, as seen in Uaxactún Group H (Valdés, 1986; Kovač and Arredondo, 2010). Thus basal platforms are perceived as representations of mountains, a universal connection among the ancient Maya. But other symbols and features further specify qualities of that mountain. It seems to be strongly connected with water, perhaps even emerging from it, as some friezes present aquatic symbols and creatures, as fish and reptilians. Perhaps the most obvious aquatic iconography has been discovered on the Southern Group H at Uaxactún, where the Witz monsters rest on the shark heads. The Lamanai Triadic Group N9-56 stucco mask bears a badly destroyed depiction of a reptilian.

The circular basin in front of the Danta Triadic at El Mirador, and the Naranjo association of Triadics with caves stands in accordance with the Flower Mountain imagery as having the cave at its base (Suyuc et al., 2008: 527-529; Fialko, 2004; Saturno et al., 2005: 16).

The personages inhabiting the Triadic Witz can be identified by their more or less explicit attributes constituting parts of the stucco decorations. One of the most recurring elements of the masks is a trilobed motif, either dangling down from the ear-spools, as for example at El Tigre/Itzamkanac, Uaxactún, and Nakbé, or forming part of the masks' headbands, for example at Cerros and Uaxactún (Schele and Freidel, 1990: 112-113; Valdés, 1986; Forsyth and Acevedo, 1994; Vargas and Delgado, 2003). This element has been widely accepted as a pars pro toto depiction of the Jester God, which, in turn, is one of the Maize God impersonations deriving from the Olmec tradition (Skidmore, 2011; Fields, 1991). Hence Christophe Helmke's reading of the Northern H Group Triadic name at Uaxactún as "The Mountain of Jester God" can be further extended as "The Mountain of Maize God" (Kovač and Arredondo, 2010: 438).

As to other personages involved in Triadic Group symbolic representation, they cannot be identified so sharply. The resurrection scenes known in Maya imagery feature various pairs of deities, and so do the artistic programs of the Triadics. This ambiguity may derive from different versions of that myth prevailing in particular regions and times. However, on a basic level, all of them display a coherent system of cultural symbols that might be semantically correlated. And so most of the stucco masks feature abundant jaguarian traits that relate to the 
Jaguar Gods. This group of deities has been identified with opposing, but complimentary forces of the universe, representing solar and lunar aspects of the sky, diurnal and nocturnal sun, light and darkness, and also certain aspects of both Hero Twins (Miller and Taube, 1993: 103-104). The swirling or wavy elements protruding from the stucco heads' maws are the breath scrolls, and it was shown by Taube (2004) that the Wind God was a prominent personage connected with the Flower Mountain, along with his companion god of rain, Chahk. These two, often depicted in a struggle, symbolically denote the frequent natural phenomenon of strong wind followed by pouring rain, so desired by maize farmers. In fact some of the earliest representations of resurrection scenes depict Chahk as one of Maize God assistants during his revival. It is no coincidence that the San Bartolo murals that vividly tell the story of Maize God's resurrection and accession to the heavenly throne adorn the walls of a temple that was subsequently converted into a Triadic Group. The West Wall mural features a dancing figure of Maize God flanked by Chahk and Terrestrial Water God, both pointing their index fingers at him. Houston and colleagues interpret this gesture as denoting the speech of importance and authority (Houston et al., 2006: 250). On the other hand, the Cross Group at Palenque features GII and GIII as flanking the central GI deity that is a local version of the Maize God. According to Stuart and other scholars, GII is a fusion of the lightning god K'awiil and an aspect of the Jaguar God (Stuart, 2005: 174-175). GIII bears both solar and feline symbols, thus fitting within the general picture of the resurrection event. Several motifs distinguished by Estrada- Belli from the Cival Triadic masks point towards a triple set of beings associated with GI / Maize God, Chahk, and Sun God (K'inich Ajaw), with some traces of serpent and avian symbolization, which constitutes the Flower Mountain complex as well (Estrada-Belli, 2006; Taube, 2004).

The oversized ear-spools that are most prominent features of virtually all the stucco masks discovered in connection with the Triadic Groups have been sometimes interpreted as denoting the b'ih, or "road" glyphs, especially when bearing four dots around the central opening. Taube (2004) argues that they might be standing for two separate symbols. One would be a well known expression och' b'ih, "entering the road", regularly describing someone's death, but in this sense more probably standing for the Maize God's entering the path of resurrection and accession to heaven through the Flower Mountain. The other meaning comes from the association of ear-flares with flowers (idem). Thus the stucco ear-spools bore the clear designation of the Flower Mountain toponym and the action of the Maize God's accession to heaven through a metaphorical portal.

The Triadic architectural layout also stands in accordance with the resurrection scene. On the top of the Flower Mountain, a central personage (Maize God) is further elevated towards the sky in his shrine, meanwhile two other beings, opposing but symmetrical and complimentary to each other, flank him, and perhaps also protect, guarding and controlling the access to the newly reborn deity. 


\section{Cultural Perception of Triadic Architecture-An Emic Perspective}

In a way, both function and meaning are products of mind. When in need, human beings search for tools and devices that would facilitate desired actions, and if they find none, then they design new ones for that purpose. In most cases the process of designing and creating an object is conducted with a specific function in mind. This holds true for material and ethereal human products, be they using a stick for planting, a pot for cooking, creating an instrument to play a song, or building a structure to fulfill a ceremonial purpose - these activities differ only in scale and complexity.

Meaning usually comes second to function and consists of the sum of emotions evoked by an existing object. Meaning may be much more variable than function, because the perception of any given object is subjective and therefore the emotions evoked by the object are specific to an individual and are prone to evolution as an individual changes. The way that one regards an object is a fusion of a personal cognitive map and a learned or imposed set of cultural traits. However, some human products may have possessed fixed meanings as a preconceived quality, especially when designed as essentially symbolic representations of other products or ideas. A logical problem arises, though, upon the realization that a cultural relation between an original object and its symbolic representation may be reciprocal with both ends interacting and influencing each other in a somewhat circular fashion. Ancient Maya architecture provides an excellent example of such a reciprocity of meaning, as was shown earlier in the discussion of the significance of the three-stone hearth.

To undertake the task of reconstructing function and meaning of ancient Maya architecture is to work backward from the final product into the minds of its long-gone creators, while simultaneously working forward in pursuit of its cultural reception. Considering the usually incomplete nature of the product itself, and the elusive and distorted contemporary perception of both its creators and receptors, one can hardly hope to go beyond a speculative and theoretical exercise. Moreover, as remarked by David Webster in his epistemological essay (1998: 16), using common sense explanations can be, and in fact frequently is, misleading. He also states that the overall task of interpreting meaning is by no means futile or counter-productive (ibid.: 17). If approached carefully and with an awareness of the limitations in an etic interpretation, it may yield an important and insightful contribution to modern understanding of the ancient Maya in general.

The greater part of this paper has been carried out by approaching Triadic Groups from an "etic", or external, vantage point. It has focussed on the form, context, and decoration of architecture, and then juxtaposed these elements with cultural motifs that appeared to be likely symbolic prototypes of the whole design. Having grasped the probable interpretation, an essential refinement has to be made. I will attempt to look at triadic architecture with the eyes of ancient 
Maya, bearing in mind that such an "emic" endeavor is necessarily infected and distorted by one's own cognitive filters.

Recent studies have resulted in a great deal of publications concerning Maya use of space and urban design. A tool especially well suiting that purpose was provided by the development of built environment studies (Lawrence and Low, 1990). General consensus among scholars regarding ancient Maya cities as local representations of the Maya cosmos has been further scrutinized with focus on particular elements comprising the artificially constructed landscapes charged with meaning. Great paved plazas spreading within cores of monumental centers, apart from their function for holding masses of subjects during ceremonial activities performed on lofty pyramids, have been proven to fulfill yet another important task, that of water catchment areas during the rainy season. Expertly designed water channels were directing rainfall towards aguadas, for storage during dry seasons (Nicolaus Seefeld, personal communication, January 2013; French et al., 2006). Thus some scholars propose an interpretation of plazas as nahb, the symbolic ocean, out of which buildings emerge as the mountains emerged during creation of the world (Wagner, 2006: 290). Recent epigraphic studies have shown that the ocean glyph possessed a phonetic value in addition to the nahb pronunciation, reading as polaw (Stone and Zender, 2011: 141). Additionally, the semantic extension of witz to denoting a pyramid has been completed by another sign of unknown reading that explicitly depicts an architectural substructure. Perhaps, then, the witz glyph stood for the whole conceptual entity of a pyramid with its temples, deities, and rituals, meanwhile the pyramid glyph operated on a more literal level, describing the architectural structure itself (ibid.: 105).

Such an ambiguity of representations stands in accordance with an apparent inclination of the Maya towards constructing subtle interplays of different meanings and attributing multiple functionality to particular objects. This, in turn, evokes two important questions: did all the architectural complexes classified as Triadic Groups originally represent the same cultural concept? In other words, is the Maize God's resurrection, as proposed above, a universal meaning for Triadics? And what was the function of Triadic Groups, which is to say what kind of ritual activities were performed within the three structures on the summits of Triadic Groups?

Before answering these question it must be realized that modern understanding of ancient Maya usage of temples is a mere assumption. Miller and Taube (1993: 161) note that

[a]mong Mesoamerican cities known only archaeologically, the word temple has often been applied without specific knowledge of any religious practices that may have taken place there. What have been termed Maya "temples" and "palaces", for example, seem to grade into one another, and in recent years, archaeologists have preferred to give structures neutral numbers rather than nicknames like "Temple of the Giant Jaguar". Nevertheless, Maya temples can generally be identified: a temple 
has a high platform topped by small chambers; access is limited and is usually by a single staircase, although a few examples have other arrangements (...) Although clearly associated with specific deities, these Maya temples primarily commemorated royal ancestors and the gods with whom the kings were united with in death.

That is precisely what seems to have happened in Palenque. The Cross Group seems to have been designed to serve the specific purpose of complex accession rituals for K'an Bahlam, but selection of a very particular triadic layout was a premeditated allusion to the Maize God's accession to heavenly rulership. Thus, in common perception of his subjects the king was equated with one of the most important divine personages of ancient Maya religion. Even if an average maize farmer who's knowledge of other urban centers had been very limited and he did not immediately understand the depth of this metaphor, he must have been familiar with divine concepts of life, death, and resurrection of the Maize God, whom he himself symbolically tended, sacrificed, and witnessed resurrecting, year after year. An elite member, in turn, exercised a more profound grasp of mythology, and was perhaps aware of other Triadic Groups existing in neighboring centers since at least a few centuries before.

In similar fashion the Flower Mountain concept might have endured until the times of Postclassic Qumarkaaj. The Popol Vuh mentions a triad of temples featuring the triadic layout, constructed for the K'iche Triad (Christenson, 2007: 267). Although their principal function is overtly stated as to house particular gods, the Flower Mountain appearance in the same account suggests the underlying, perhaps not even entirely consciously perceived ancient significance of that architectural complex.

Considering the relatively rapid appearance of triadic architecture during the Preclassic period, it may be safely assumed that this then-innovative way of representing the myth of the death and rebirth of the Maize god, that may have perhaps already existed for a long time, was initially adopted with its basic meaning. It subsequently evolved adding other dimensions that served to enforce the local purposes. The concept of Flower Mountain as the Maize God's entrance to heaven was so powerfully charged with important religious messages that it probably would not have been overlooked by the agents with the means to enforce the legitimacy of their elevated social status by building these Triadic Groups.

As previously mentioned, an emic perspective further enforces the plausibility of resurrection story as the basic meaning of Triadics, at the expense of the episode of the Underworld journey. Intuitively, the former is a moment of glory and relief, meanwhile the latter evokes entirely opposite connotations. Although it is not improbable that some ritual activities existed that metaphorically pleaded certain gods for positive conclusion of the Maize God's misfortune, the mere size and grandeur of Triadic Groups suggests some glorious and monumental cultural associations rather than those of insecurity and anticipation. Another minor but possibly relevant argument can be made when looking on the canoe scenes. Both 
Paddler gods that accompany the Maize God, more often than not look outward in their difficult task of maneuvering through the water, meanwhile the resurrection witnesses invariably face the principal deity. The triadic layout features exactly the same paoern, to the point where Cerros Triadic Group 29 manages to squeeze two inward looking lateral plasorms leaving liole space for actual access to either (Schele and Freidel, 1990: 125). This disregard of access ways caused by extremely limited space most liley shows the intention of using the platforms to mimic the tableau of witnesses to the Maize God's resurrection.

As to variable cardinal orientation of Triadic Groups, two observations can be made. Unlike the astronomical representations, the Flower Mountain concept does not seem to have any specific, universally accepted geographic location within the universe. Moreover, specific distribution of scenes concerning the Maize God's resurrection has not ever been cardinally oriented. Perhaps, then, Triadics were constructed on localities and orientations that fitted well in the urban canvass at the moment, without losing the most important metaphorical connotations. However, at the first stage of Triadic Groups appearance the eastern orientation seems to be favoured, perhaps due to its general connotation with life and resurrection evoked by the rising sun (Miller and Taube, 1993: 77-78; Freidel et al., 1993: 128). Classic Period shift towards the north as a more preferred direction might have been dictated by two separate factors. In general, the Classic worldview attached specific qualities to different cardinal directions, with the north associated with fortune, new life, and the rainy season, during which the maize plant grows (Christenson, 2007: 181). The second factor regards only a limited array of north-oriented Triadics with all three superstructures of approximately similar size, as for example the North Acropolis at Yaxhá. During the development of Triadic symbolism, resulting in stacking and overlapping different functions and meanings, a group of Triadics may have indeed represented the Celestial Hearth constellation, among other things, as originally proposed by Freidel et al. (1993).

Although Miller and Taube argue that the principal function of ancient Maya temples was to commemorate rulers (op. cit.), in the case of Triadic Groups this function might have in fact been secondary, with the original actors of the resurrection scene being the likely candidates for the patrons of each temple. The nature of rituals performed within particular sanctuaries is best left for the imagination rather than scientific investigations. However, according to Hansen (op. cit.), the peculiar order of activities in regard of the kin's accession recorded on the walls of the Cross Group at Palenque may reflect a more general paoern. Thus, the lateral shrines, perhaps devoted to the Hero Twins, or Chahk and K'awiil, would house bloodledng rituals performed by the king to please and enforce the divine attendants, meanwhile the central, Maize God temple would witness his formal enthronement and offering of the ruler's headband, as seen on the San Bartolo west wall mural (Saturno et al., 2005; Taube et al., 2010). Considering the vast amount of iconographic depictions of the Maize God in the act of dancing after 
his rebirth, a ritual dance performed by the king may have also been part of activities conducted in front of the central shrine (cf. Grube, 1992).

\section{Conclusions}

No great endeavor can be brought to a conclusion without planning, and at least a vague vision of the final result. And since construction of monumental architecture was no doubt a very laborious and costly enterprise, ancient Maya builders must have had specific purposes for each structure before commencing the process of building them. As was indicated at the beginning of this work, a rather partiular layout of Triadic Groups recurred for nearly fifteen centuries in the Maya area, implicating some very persistent and important ideas as a motive driving the whole societies to elevate those huge platforms and pyramids time and time again.

One model has proven to concur particularly well with the archaeological and other data regarding Triadics. This model interprets Triadic Groups as symbolic monuments commemorating the Maize God and the act of his resurrection upon Flower Mountain. According to a variety of sources, mainly iconographic and epigraphic, the Flower Mountain was a paradise of creation, life, and abundance, and connected the three realms of the Maya universe. The resurrection of the Maize God took place on the top of that mountain and was attended by a pair of complimentary deities representing forces allowing and assuring the growth of maize plants, most likely the Hero Twins, Gods of Rain and Wind, the Sun and the Moon, or perhaps a fusion of these entities.

The mythical story about the Maize God was pivotal for ancient Maya people, who were maize farmers and agriculturalists. It must have evoked selfidentification across all levels of ancient Maya societies from the humblest farmers attending to maize on their milpas on a daily basis, to the kings themselves. All of them routinely identified with the Maize God and his post-mortem destiny through their acts of production and consumption of maize. Triadic Groups then were so powerfully loaded with important religious messages that they eventually grew in value and became cultural symbols of their own, perhaps with the original concept of death and rebirth of the Maize God slightly diminished under layers of secondary functions and meanings.

This conclusion, however, evokes a number of secondary questions. Not the least important of them is: if the Maize God myth is indeed so essential and the Triadic Groups are indeed the stages of its reenactment, why do many of the Preclassic and Classic sites lack this kind of architecture? Was there another type of specialized space that could replace a Triadic layout in the veneration of the Maize God? Perhaps the presence of Triadics was linked to a specific type of political organization within a given site, such as one with a centralized ruler and a strong social hierarchy, whereas the sites without Triadics exercised more egalitarian political 
systems. This question cannot be answered presently, but perhaps the constant stream of new data will bring more clues concerning that topic in the future and verify ideas comprised within this paper. 


\section{BIBLIOGRAPHY}

Anderson, D.

2005 "A Report on Activities at Xtobó, Yucatán, México". Electronic report <www. docstoc.com/docs/29472273/A-Report-on-Activities-at-Xtobo-YucatanMexico-Un>.

Aveni, A.

2001 Skywatchers. Austin: University of Texas Press.

Aveni, A., A. Dowd and B. Vining

2003 "Maya Calendar Reform? Evidence from Orientations of Specialized Architectural Assemblages", Latin American Antiquity, 14 (2): 159-178. Washington, D.C.: Society for American Archaeology.

Avilés, M.

2000 "The Archaeology of Early Formative Chalcatzingo, Morelos, México. 1995". FAMSI Electronic report <www.famsi.org/reports/94047/94047Aviles01.pdf>.

Brady, J. and K. Prufer

2010 In the Maw of the Earth Monster: Mesoamerican Ritual Cave Use. Austin: University of Texas Press.

Carmack R. and J. Weeks

1981 "Archaeology and Enthnohistory of Utatlán: a Conjunctive Approach", American Antiquity, 46 (2): 323-341. Washington, D.C.: Society for American Archaeology.

Cohodas, M.

1985 "Public Architecture of the Maya Lowlands", Cuadernos de Arquitectura Mesoamericana, 6: 51-68. México: Universidad Nacional Autónoma de México, Facultad de Aquitectura.

Copeland, D.

1989 Excavations at the Monos Complex, El Mirador, Petén, Guatemala. Provo, Brigham Young University (Papers of the New World Archaeological Foundation, 61).

Chase A. and D. Chase

1987a "Glimmers of a Forgotten Realm: Maya Archaeology at Caracol, Belize". Orlando: University of Central Florida.

1987b Investigations at the Classic Maya City of Caracol, Belize: 1985-1987. San Francisco: Pre-Columbian Art Research Institute (Monograph, 3).

2001 "Continued Investigation into Epicentral Palaces: Report of the 2001 Field Season at Caracol, Belize". Electronic report <www.caracol.org/reports/2001. php>.

Christenson, A.

2007 Popol Vuh. Sacred Book of the Quiche Maya People. MESOWEB electronic version <www.mesoweb.com/publications/Christenson/PopolVuh.pdf $>$. 
Estrada-Belli, F.

2006 "Lightning Sky, Rain, and the Maize God: The Ideology of Preclassic Maya Rulers at Cival, Petén, Guatemala”, Ancient Mesoamerica, 17: 57-78. Cambridge: Cambridge University Press.

2011 The First Maya Civilization: Ritual and Power Before the Classic Period. New York: Routledge.

Fialko, V.

2004 "Investigaciones arqueológicas en la Acropolis Triadica B-5 de Naranjo", XVII Simposio de Investigaciones Arqueológicas en Guatemala, 2003, pp. 570581, Laporte J., B. Arroyo and H. Mejía (eds.). Guatemala: Museo Nacional de Arqueología y Etnología.

Fields, V.

1991 "The Iconographic Heritage of the Maya Jester God", Sixth Palenque Round Table, 1986, pp. 167-174, Green Robertson M. and V. Fields (eds.). Norman, University of Oklahoma Press.

Flores, A.

2010 "Los complejos del Tipo ‘E’ y su asociación con acrópolis o arreglos de tipo triádico: Esbozos de un posible patrón urbano y sus posibles significados", XXIII Simposio de Investigaciones Arqueológicas en Guatemala, 2009, pp. 11122, Arroyo B., A. Linares and L. Paiz (eds.). Guatemala: Museo Nacional de Arqueología y Etnología.

Folan, W., J. Gunn and M. Domínguez Carrasco

2001 "Triadic Temples, Central Plazas, and Dynastic Palaces: A Diachronic Analysis of the Royal Court Complex, Calakmul, Campeche, México", Royal Courts of the Ancient Maya, vol. 2: Data and Case Studies, pp. 223-265, Inomata T. and S. Houston (eds.). Boulder: Westview.

Folan, W. J. Marcus, et al.

1995 "Calakmul: New Data from an Ancient Maya Capital in Campeche, México", Latin American Antiquity, 6 (4): 310-334. Washington, D.C.: Society for American Archaeology.

Forsyth D. and R. Acevedo

1994 “La Estructura 27 de Nakbé, Petén”, VII Simposio de Investigaciones Arqueológicas en Guatemala, 1993, pp. 253-263, Laporte J. and H. Escobedo (eds.). Guatemala: Museo Nacional de Arqueología y Etnología.

Freidel, D.

1986 "Monumental Architecture", Archaeology at Cerros Belize, Central America, vol. I, An Interim Report, pp. 1-22, Robertson R. and D. Freidel (eds). Dallas: Southern Methodist University Press.

2005 "The Creation Mountains: Structure 5C-2nd and Late Preclassic Kingship", Lords of Creation: The Origins of Sacred Maya Kingship, pp. 52-53, Fields V. and D. Reents-Budet (eds.). Los Angeles: Scala Publishers. 
Freidel, D., L. Schele and J. Parker

1993 Maya Cosmos: Three Thousand Years on the Shaman's Path. New York: Harper Collins.

Freidel, D., K. Reese-Taylor and M. Mora-Marín

2002 "The Origins of Maya Civilization: The Old Shell Game, Commodity, Treasure, and Kingship", Ancient Maya Political Economies, pp. 41-86, Mason M. and D. Freidel (eds.). New York: Altamira.

French, K., D. Stuart and A. Morales

2006 "Archaeological and Epigraphical Evidence for Water Management and Ritual at Palenque", Mesoamerican Water Management, pp. 144-152, Lucero L. and B. Fash (eds.). Tucson: University of Arizona Press.

García, E.

2001 "Investigaciones en la parte norte de Yaxhá", XIV Simposio de Investigaciones Arqueológicas en Guatemala, 2000, pp. 113-130, Laporte J., A. Suasnavar and B. Arroyo (eds.). Guatemala: Museo Nacional de Arqueología y Etnología.

Grove, D.

1970 The Olmec Paintings of Oxtotitlán Cave, Guerrero, México. Studies in Pre-Columbian Art and Archaelogy, 6. Washington, D.C.: Dumbarton Oaks.

Grube, N.

1992 "Classic Maya Dance. Evidence from Hieroglyphs and Iconography”, Ancient Mesoamerica, 3: 201-218. Cambridge: Cambridge University Press.

Hansen, R.

1990 Excavations in the Tigre Complex, El Mirador, Petén, Guatemala. Provo: Brigham Young University (Papers of the New World Archaeological Foundation, 62).

1998 "Continuity and Disjunction: The Pre-Classic Antecedents of Classic Maya Architecture", Function and Meaning in Classic Maya Architecture, pp. 49-122. Washington, D.C.: Dumbarton Oaks Research Library and Collection.

2002 "The Architectural Development of an Early Maya Structure at Nakbé, Petén, Guatemala". FAMSI, electronic report < www.famsi.org/reports/95113/95113Hansen01. pdf $>$.

Hansen, R. et al.

2005 "Un katún de espera en El Mirador, Petén: Sondeos y re-excavación de la Estructura 34 del Preclásico Tardío”, XVIII Simposio de Investigaciones Arqueológicas en Guatemala, 2004, pp. 55-68, Laporte J., B. Arroyo and H. Mejía (eds.). Guatemala: Museo Nacional de Arqueología y Etnología.

Headrick, A.

2007 The Teotihuacan Trinity. The Sociopolitical Structure of an Ancient Mesoamerican City. Austin: University of Texas Press. 
Houston, S., D. Stuart and K. Taube

2006 The Memory of Bones. Body, Being, and Experience among the Classic Maya. Austin: University of Texas Press.

Howell, W. and D. Evans Copeland

1989 Excavations at El Mirador, Petén, Guatemala: The Danta and Monos Complexes, El Mirador Series, Part 2. Provo: Brigham Young University (New World Archaeological Foundation Paper 60-61).

Inomata, T.

2006 "Plazas, Performers, and Spectators: Political Theaters of the Classic Maya", Current Anthropology, 47 (5): 805-842. Chicago: The University of Chicago Press.

Koszkul, W., J. Źrałka, B. Hermes and J. Lopez

2008 "Proyecto Arqueológico Nakum: Informe Preliminar, Temporada 2008", Kovač M. and E. Arredondo Leiva (eds.). Kraków, Poland: Jagiellonian University.

2010 "Proyecto Arqueológico SAHI-Uaxactún. Informe No. 2, Temporada de Campo 2010", unpublished field report, SAHI Bratislava.

Lawrence, D. and S. Low

1990 "The Built Environment and Spatial Form", Annual Review of Anthropology, 19: 453-505. Palo Alto: Clearance Center.

Loten, S.

2007 "Additions and Alterations: A Commentary on the Architecture of the North Acropolis, Tikal, Guatemala, Tikal Reports 34A". Philadelphia: University of Pennsylvania.

Lounsbury, F.

1985 "The Identities of the Mythological Figures in the Cross Group Inscriptions of Palenque", Fourth Palenque Round Table, Benson E. (ed.), pp. 45-58. San Francisco: PARI.

Martin, S. and N. Grube

2008 Chronicle of the Maya Kings and Queens. London: Thames \& Hudson.

Matheny, R.

1987 “Update, Project El Mirador, Petén, Guatemala”, Mexicon, 9 (4): 85-91. Germany: Verlag Anton Saurwein.

Miller, M.

1999 Maya Art and Architecture. London: Thames and Hudson.

Miller M. and K. Taube

1993 An Illustrated Dictionary of Gods and Symbols of Ancient México and the Maya. London: Thames and Hudson. 
Morales Aguilar, C., R. Hansen, A. Morales López and W. Howell

2008 "Nuevas perspectivas en los modelos de asentamientos mayas durante el Preclásico en las Tierras Bajas: Los sitios de Nakbé y El Mirador, Petén”, XXI Simposio de Investigaciones Arqueológicas en Guatemala, 2007, pp. 198-213, Laporte J., B. Arroyo and H. Mejía (eds.). Guatemala: Museo Nacional de Arqueología y Etnología.

Nalda Hernández, E. et al.

1994 “Sur de Quintana Roo: Dzibanché y Kinichná”, Arqueología Mexicana, 2 (10): 14-19. México: Raíces.

Pendergast, D.

1981 “Lamanai, Belize: Summary of Excavation Results, 1974-1980”, Journal of Field Archaeology, 8 (1): 29-53. USA: Boston University.

Pool, Ch.

2007 Olmec Archaeology and Early Mesoamerica. New York: Cambridge University Press.

Rice, D.

1976 "Middle Preclassic Maya Settlement in the Central Maya Lowlands", Journal of Field Archaeology, 3 (4): 425-445. Philadelphia: Maney Publishing INC.

Ricketson, O. and E. Ricketson

1937 Uaxactún, Guatemala: Group E, 1926-1931. Washington, D.C.: Carnegie Institution (Publication, 477).

Saturno, W., K. Taube and D. Stuart

2005 The Murals of San Bartolo, El Petén, Guatemala. Part 1: The North Wall, Ancient America, 7. Ashville: BEARC.

Schele, L. and D. Freidel

1990 A Forrest of Kings: the Untold Story of the Ancient Maya. New York: Morrow.

Skidmore, J.

2011 "Earliest Jester God Found at K'o, Guatemala", Mesoweb online publication $<$ www.mesoweb.com/reports/ EarliestJesterGod.pdf $>$.

Stone, A. and M. Zender

2011 Reading Maya Art: A Hieroglyphic Guide to Ancient Maya Painting and Sculpture, London: Thames and Hudson.

Stuart, D.

2005 The Inscriptions from Temple XIX at Palenque. San Francisco: Precolumbian Mesoweb Press.

Suyuc Ley, E. and R. Hansen (eds.)

2006 "Investigación y conservación en los sitios arqueológicos El Mirador, La 
Muerta, Wakná, El Porvenir, El Güiro, La Iglesia, La Sarteneja, Chab Che' y La Ceibita: Informe Final de la Temporada 2005”. Guatemala: IDAEH.

Suyuc Ley, E., P. Morales, F. López and Anaite Ordóñez

2008 "Investigaciones en el complejo arquitectónico Danta, El Mirador, Petén", XXI Simposio de Investigaciones Arqueológicas en Guatemala, 2007, pp. 525-543, Laporte J., B. Arroyo and H. Mejía (eds.). Guatemala: Museo Nacional de Arqueología y Etnología.

Šprajc, I.

2008 Reconocimiento arqueológico en el sureste del estado de Campeche, México. Oxford: Archeopress (BAR International Series 19).

Šprajc, I., C. Morales-Aguilar and R. Hansen

2009 "Early Maya Astronomy and Urban Planning at El Mirador, Petén, Guatemala”, Anthropological Notebooks, 15 (3): 79-101. Slovenia: Slovenian Anthropological Society.

Taube, $\mathrm{K}$.

1996 "The Olmec Maize God: The Face of Corn in Formative Mesoamerica”, RES: Anthropology and Aesthetics, 29/30: 39-81. Cambridge: Harvard University Press and Peabody Museum of Archeology and Ethnology.

1998 "The Jade Hearth: Centrality, Rulership, and the Classic Maya Temple", Function and Meaning in Classic Maya Architecture, pp. 427-478. Washington, D.C.: Dumbarton Oaks Research Library and Collection.

2004 "Flower Mountain: Concepts of Life, Beauty, and Paradise among the Classic Maya”, RES: Anthropology and Aesthetics, 45: 69-98. Cambridge: Harvard University Press and Peabody Museum of Archeology and Ethnology.

2006 "The Classic Maya Gods”, Maya. Divine Kings of the Rain Forest, pp. 262-279, N. Grube (ed.). Germany: Tandem-Verlag.

Taube, K., W. Saturno, D. Stuart and H. Hurst

2010 The Murals of San Bartolo, El Petén, Guatemala. Part 2: The West Wall, Ancient America vol. 10. Ashville: BEARC.

Tozzer, A.

1913 "A Preliminary Study of the Prehistoric Ruins of Nakum, Guatemala: A Report of the Peabody Museum Expedition, 1909-1910". Cambridge: Peabody Museum of American Archaeology and Ethnology.

Vail, G.

2000 "Pre-Hispanic Maya Religion. Concepts of Divinity in the Postclassic Maya Codices", Ancient Mesoamerica, 11: 123-147. Cambridge: Cambridge University Press.

Valdés, J.

1986 “Los mascarones preclásicos de Uaxactún: el caso del Grupo H”, Primer Simposio de Epigraía Maya. Guatemala: Museo Nacional de Arqueología y Etnología (manuscript). 
1989 "El Grupo A de Uaxactún: Manifestaciones arquitectónicas y dinásticas durante el Clásico Temprano”, Mayab, 5: 30-40. Madrid: Sociedad Española de Estudios Mayas.

Vargas Pacheco, E. and A. Delgado Salgado

2003 "La estructura 1 (o de Los Mascarones), El Tigre, Campeche: Reconstrucción hipotética”, XVI Simposio de Investigaciones Arqueológicas en Guatemala, 2002, pp. 982-993, Laporte J., B. Arroyo, H. Escobedo and H. Mejía (eds.). Guatemala: Museo Nacional de Arqueología y Etnología.

Vogt, E. and D. Stuart

2010 "Some Notes on Ritual Caves among the Ancient and Modern Maya", In the Maw of the Earth Monster: Mesoamerican Ritual Cave Use, pp. 155-185, Brady J. and K. Prufer (eds.). Austin: University of Texas Press.

Wagner, E.

2006 "Maya Creation Myths and Cosmography", Maya. Divine Kings of the Rain Forest, pp. 281-292, N. Grube (ed.). Germany: Tandem Verlag.

Walker, D.

2005

"Sampling Cerros' Demise: A Radiometric Check on the Elusive Protoclassic". FAMSI, electronic report <www.famsi.org/reports/03064/03064Walker01.pdf>.

Webster, D.

1998 "Classic Maya Architecture: Implications and Comparisons”, Function and Meaning in Classic Maya Architecture, pp. 5-48, S. Houston (ed.). Washington, D.C.: Dumbarton Oaks Research Library and Collection.

Źrałka, J.

2007 "The Nakum Archaeological Project: Investigations on the Banks of the Holmul River, Guatemala”. FAMSI, electronic report <www.famsi.org/ reports/06022/06022Zralka01.pdf $>$.

2008 Terminal Classic Occupation in the Maya Sites Located in the Area of Triángulo Park, Petén, Guatemala. Krakow: Jageillonian University Press (Prace Archeologiczne, 62).

Źrałka, J. and B. Hermes

2012 "Great Development in Troubled Times: The Terminal Classic at the Maya Site of Nakum, Petén, Guatemala”, Ancient Mesoamerica, 23 (1): 161-187. Cambridge: Cambridge University Press.

Źrałka, J. et al.

2011 "Proyecto Arqueológico Nakum: Informe Final, Temporada 2011". Guatemala: IDAEH. 